\title{
Imide and isatin derivatives as $\gamma$-lactam mimics of ß-lactam antibiotics
}

\author{
Peter S Hadfield ${ }^{\mathrm{a}}$, Lorraine A Casey ${ }^{\mathrm{a}}$, Ronald H B Galt ${ }^{\mathrm{b}}$, \\ Bartholomew Vilanova $^{\mathrm{a}}$, and Michael I Page ${ }^{\mathrm{a}^{*}}$ \\ a Department of Chemical and Biological Sciences, The University of Huddersfield, \\ Queensgate, Huddersfield, HD1 3DH, UK \\ ${ }^{\mathrm{b}}$ Research Department, AstraZeneca, Alderley Park, Macclesfield, Cheshire, SK10 4TG, UK \\ E-mail: m.i.page@hud.ac.uk
}

Dedicated to Professor Charles Rees on his $75^{\text {th }}$ birthday

(received 20 Jun 02; accepted 15 Aug 02; published on the web 23 Aug 02)

\begin{abstract}
Activated $\gamma$-lactams, which are derivatives of succinimide, phthalimide and isatin with suitable elements of molecular recognition, have been synthesised as mimics of the ß-lactam antibiotics and their chemical and biological reactivity determined.
\end{abstract}

Keywords: $\gamma$-Lactams, imides, isatins, antibacterials, ß-lactamase, hydrolysis

\section{Introduction}

The traditional antibiotics which interact with the bacterial enzymes, the DD-peptidases and the $ß$-lactamases, are ß-lactams, for example, benzyl penicillin, 1. The strain energy inherent in the four-membered ring and the non-planarity of the $\beta$-lactam were, for many years, thought to be vital for this activity which involves the acylation of an active site serine residue. ${ }^{1}$ However, it has been demonstrated that the chemical reactivity of ß-lactams is not unusual and that molecular recognition is as equally important as acylating power. ${ }^{2}$ Furthermore non-ß-lactam derivatives such as $\gamma$-lactams may show chemical reactivity similar to that of the classical penicillins and cephalosporins $^{3}$ and consequently offer the potential to act as inhibitors of the bacterial enzymes. We report here the synthesis of activated $\gamma$-lactams, e.g. 2 and $\mathbf{3}$ as structural mimics of the classical ß-lactam antibiotics. 


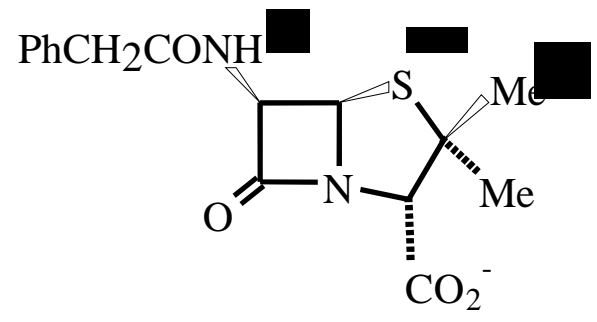

1<smiles>[13CH3][C@@H](C(=O)O)N1C(=O)CC(NC(=O)c2ccccc2)C1=O</smiles>

2<smiles>[13CH3][C@H](C(=O)O)N1C(=O)C(=O)c2ccccc21</smiles>

3

Attempts to substitute larger membered rings for the ß-lactam ring and yet retain good antibacterial activity have been tried before, for example, using imides ${ }^{4}$ and isatins ${ }^{5}$ but with little or no success. Other activated $\gamma$-lactams which have been synthesised as isosteres of the $\beta$ lactams include the pyrazolidinones, ${ }^{6}$ imidazolidinones, ${ }^{7}$ cycloserines ${ }^{8}$ and hydantoins. ${ }^{9}$ The antibacterial activity of ß-lactam antibiotics results from their acylation of the transpeptidases involved in the synthesis of the bacterial cell wall. Bacterial resistance to these antibiotics is predominantly due to the production of bacterial ß-lactamases which catalyse ring opening and hydrolysis of the ß-lactam. ${ }^{10}$ One of the problems associated with increasing the ring size from four-membered is that the 'back-reaction', ie recyclisation, may occur more readily and regenerate the free enzyme (Scheme 1).

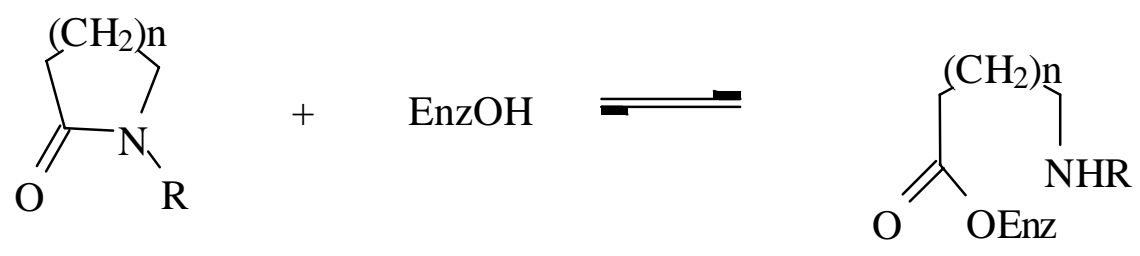

Scheme 1. Reversible ring opening.

For example, we have shown that ring closure can occur by the intramolecular aminolysis of acylenzymes to form $\gamma$-lactams but not $\beta$-lactams. ${ }^{11}$ This paper describes some attempts to discourage the recyclisation whilst retaining features required for good antibiotic activity. Activated structures based on succinimide, phthalimide and isatin which have a potential leaving group (Lg) $\alpha$-substituted to the incipient amine may not only reduce the probability of reclosure of the ring but also generate a 'second trap' for enzyme inactivation (Scheme 2). 

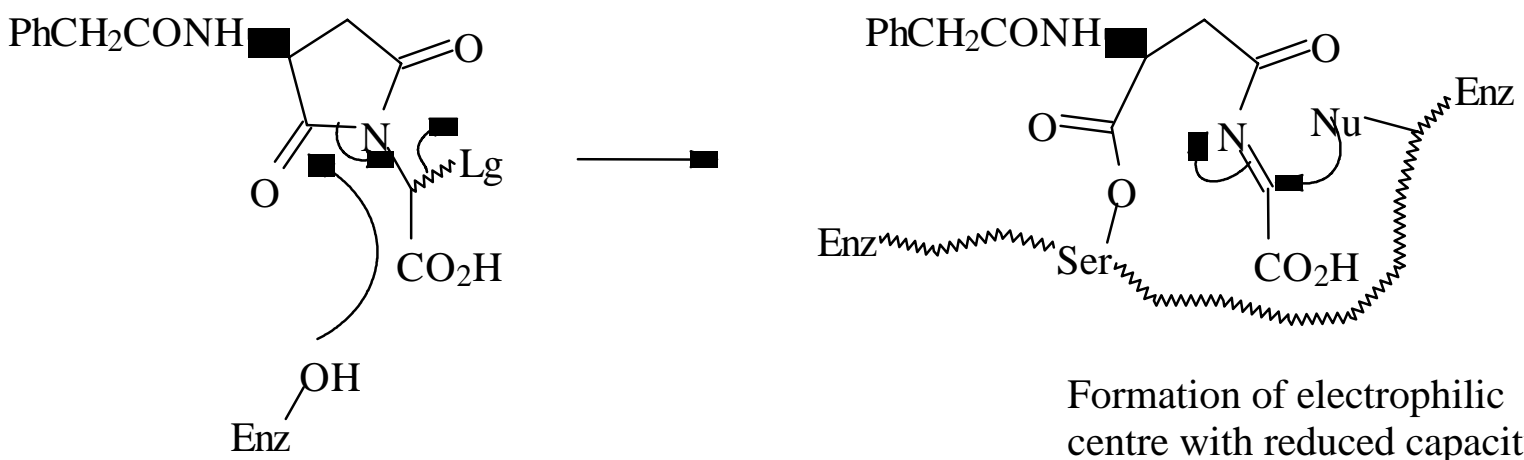

Formation of electrophilic centre with reduced capacity for ring closure

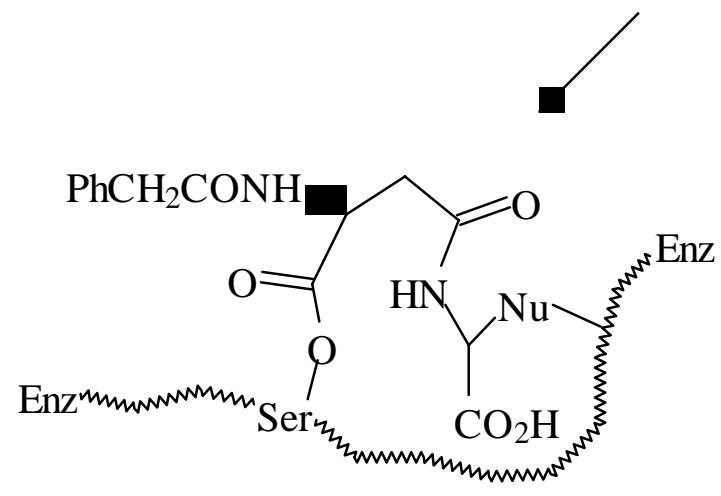

Inactivated enzyme

Scheme 2. The potential mode of action with serine enzymes of $\gamma$-lactams with a leaving.

Nucleophilic attack at the $\gamma$-lactam carbonyl followed by ring opening and concomitant elimination of the leaving group generates an electrophilic imine. As a result of expulsion of the leaving group the nucleophilicity of the nitrogen is reduced, so the ease of the 'back-reaction' and ring closure with regeneration of the free enzyme is discouraged. In addition, the electrophilic imine could also covalently react with any nucleophilic species in the active site, increasing the likelihood of enhanced inactivation, potentially resulting in autolysis and death of the bacterium.

The introduction of a second carbonyl group into a $\gamma$-lactam ring either adjacent to the nitrogen, as in phthalimide and succinimide, ${ }^{3}$ or adjacent to the carbonyl as in isatin, ${ }^{12}$ activates the amide bond sufficiently to bring its reactivity close to that of the ß-lactam of ß-lactam antibiotics. To be an effective acylating agent it appears that the second order rate constant for hydrolysis, $\mathrm{k}_{\mathrm{OH}}$, should be in the range exhibited by the biologically active penicillins and cephalosporins, ${ }^{2}$ ie 0.01 to $1 \mathrm{M}^{-1} \mathrm{~s}^{-1}$. The $\gamma$-lactams of imides and isatins, which have alkaline hydrolysis rates that fall within this range, ${ }^{2}$ are activated enough to be considered as starting points for potential antibiotics and/or inactivators of the ß-lactamase enzymes. The synthesis of 
the $\gamma$-lactam analogues of succinimide, phthalimide and isatin, is reported together with their hydrolytic and antibiotic activity and their inactivation of ß-lactamase enzymes.

\section{Results and Discussion}

The structure-activity relationships of ß-lactam antibacterial agents are not very well defined although it is clear that the minimum requirements involve good acylating power combined with the correct geometrical relationship between the acylating centre and the carboxylate anion. ${ }^{3,13}$ The compounds synthesised here represent a variety of different molecular shapes but with reactivities falling into the required range.

The $\mathrm{N}$ - $\alpha$-hydroxyacetic acid adducts of succinimide 4 (Scheme 3), phthalimide 5 (Scheme 4) and isatin 6 (Scheme 5) were synthesised by condensation with glyoxylic acid. ${ }^{14}$ The chemical shifts of the methine hydrogens in the ${ }^{1} \mathrm{H}$ NMR spectra of these structures are particularly diagnostic being at $5.67 \delta(4), 5.88 \delta(5)$ and $6.01 \delta(6)$. These adducts are unlikely to be able to expel the hydroxyl group to generate the imine trap, nonetheless they were tested for antibacterial activity, but none was found.
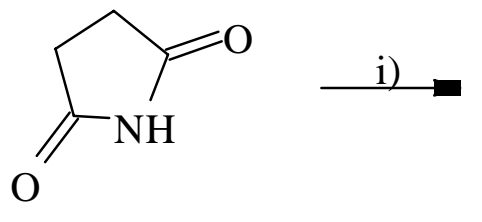

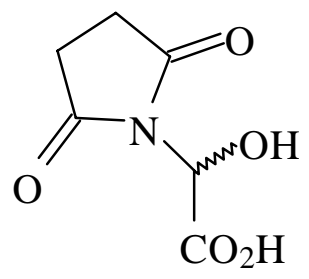

4

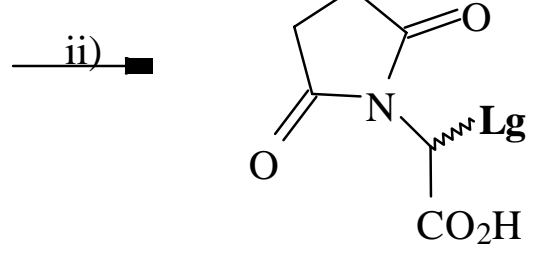

$7 \mathbf{L g}=\mathrm{Cl}$

$9 \mathbf{L g}=\mathrm{OCOCH}_{3}$

$11 \mathbf{L g}=\mathrm{OCOCH}_{2} \mathrm{Ph}$

\section{Scheme 3}

Reagents and conditions: i) Glyoxylic acid (50 wt\%), THF, reflux; ii) 7; $\mathrm{SOCl}_{2}, \mathrm{THF}, 0^{\circ} \mathrm{C}, \mathrm{H}_{2} \mathrm{O}$; 9; acetyl chloride, pyridine, $0^{\circ} \mathrm{C}$; 11; phenylacetyl chloride, pyridine, $0^{\circ} \mathrm{C}$

These adducts were found to be unstable in water and quickly decomposed to their corresponding imide and glyoxylic acid, the half-life of the isatin derivative 6 was only 2-3 minutes at $\mathrm{pH} 7$ and $20^{\circ} \mathrm{C}$. The hydroxyl function was consequently converted to a number of more convenient leaving groups. The first leaving groups to be considered were sulphonates but attempts at sulphonation of the hydroxyl group using various sulphonyl halides met with little success. For example, the reaction of $\mathbf{4}$ with either methanesulphonyl or p-toluenesulphonyl 
chloride resulted in sulphonate derivatives which were very labile and immediate decomposition occurred on attempted isolation.<smiles>CC(=O)[C@H](O)N1C(=O)c2ccccc2C1=O</smiles>

14

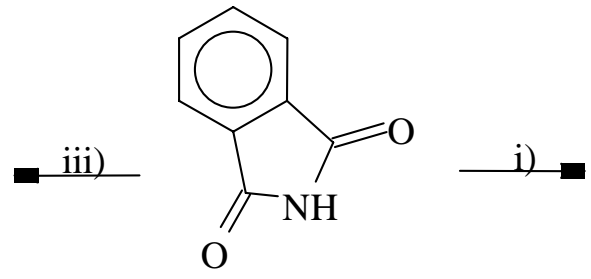

v)<smiles>CCCCCCC(=O)O</smiles>

$8 \mathbf{L g}=\mathrm{Cl}$

$10 \mathbf{L g}=\mathrm{OCOCH}_{3}$

$12 \mathbf{~} \mathbf{g}=\mathrm{OCOCH}_{2} \mathrm{Ph}$

$13 \mathbf{~ L g}=\mathrm{OCO}(\mathrm{Cl})_{2}$ Aryl

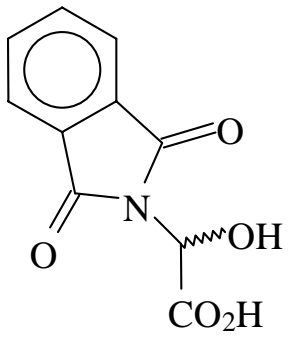

5

$$
15 \mathbf{~} \mathbf{g}=\mathrm{OCO}(\mathrm{Cl})_{2} \mathrm{Aryl}
$$

\section{Scheme 4}

Reagents and conditions: i) Glyoxylic acid (50 wt\%), THF, reflux; ii) 8; $\mathrm{SOCl}_{2}, \mathrm{THF}, 0{ }^{\circ} \mathrm{C}, \mathrm{H}_{2} \mathrm{O}$; 10; acetyl chloride, pyridine, $0{ }^{\circ} \mathrm{C}$; 12; phenylacetyl chloride, pyridine, $0{ }^{\circ} \mathrm{C}$; iii) methyl glyoxylate, THF, reflux; iv) 2,6-dichlorobenzoyl chloride, pyridine, $0{ }^{\circ} \mathrm{C}$; v) 13; $\mathrm{LiI}^{\circ} \mathrm{H}_{2} \mathrm{O}$, pyridine, reflux

Compounds 4, 5 and 6 were reacted with 2.5 equivalents of thionyl chloride to give the corresponding halides as potential leaving groups - 7, 8 and 19, respectively. The free carboxylic acid groups present in these derivatives also reacted to give rise to the formation of the corresponding acyl chlorides and their subsequent reaction with free hydroxy residues formed polymeric esters as side products. Hydrolysis of the acyl chlorides with ice water for $3 \mathrm{~h}$. followed by a work-up and trituration using dichloromethane was the best method found for purifying the products. The characteristic methine protons moved downfield to $6.42 \delta(7), 6.70 \delta$ (8) and $7.18 \delta$ (19), respectively. 


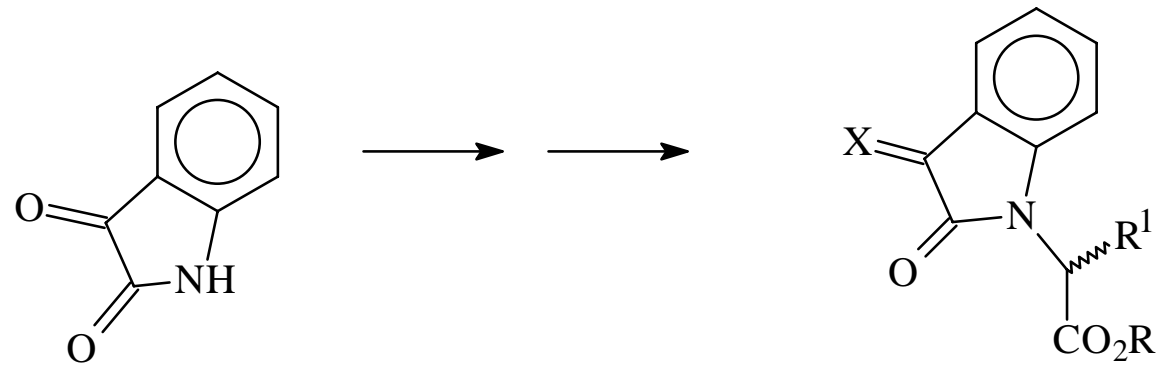

\begin{tabular}{cccc}
\hline Compound & $\mathrm{R}$ & $\mathrm{R}^{1}$ & $\mathrm{X}$ \\
\hline $\mathbf{5}$ & $\mathrm{H}$ & $\mathrm{OH}$ & $\mathrm{O}$ \\
$\mathbf{1 7}$ & $4-\mathrm{NO}_{2} \mathrm{Bn}$ & $\mathrm{OH}$ & $\mathrm{O}$ \\
$\mathbf{1 8}$ & $\mathrm{CH}_{3}$ & $\mathrm{OH}$ & $\mathrm{O}$ \\
$\mathbf{1 9}$ & $\mathrm{H}$ & $\mathrm{Cl}$ & $\mathrm{O}$ \\
$\mathbf{2 0}$ & $4-\mathrm{NO}_{2} \mathrm{Bn}$ & $\mathrm{OAc}$ & $\mathrm{O}$ \\
$\mathbf{2 1}$ & $4-\mathrm{NO}_{2} \mathrm{Bn}$ & $2,6-(\mathrm{Cl})_{2} \mathrm{Benzoyl}$ & $\mathrm{O}$ \\
$\mathbf{2 2}$ & $\mathrm{CH}_{3}$ & $\mathrm{OAc}$ & $\mathrm{O}$ \\
$\mathbf{2 4}$ & $\mathrm{CH}_{3}$ & $\mathrm{Bn}$ & $\mathrm{O}$ \\
$\mathbf{2 5}$ & $\mathrm{CH}_{3}$ & $\mathrm{Cl}$ & $\mathrm{O}$ \\
$\mathbf{2 6}$ & $\mathrm{CH}_{3}$ & $\mathrm{Br}$ & $\mathrm{O}$ \\
$\mathbf{2 7}$ & $4-\mathrm{NO}_{2} \mathrm{Bn}$ & $\mathrm{OH}$ & $\mathrm{BnON}$ \\
$\mathbf{2 8}$ & $4-\mathrm{NO}_{2} \mathrm{Bn}$ & $\mathrm{OAc}$ & $\mathrm{BnON}$ \\
$\mathbf{2 9}$ & $4-\mathrm{NO}_{2} \mathrm{Bn}$ & $2,6-(\mathrm{Cl})_{2} \mathrm{Benzoyl}$ & $\mathrm{BnON}$ \\
\hline
\end{tabular}

\section{Scheme 5}

Reaction of the glycolic acid derivatives $\mathbf{4}$ and $\mathbf{5}$ with acid chlorides gave esters 9-12 which, in the active site of the enzymes, could in principle react by expelling their corresponding carboxylate anions. Pyridine was used as both solvent and base in the synthesis but numerous purification procedures using silica gel chromatography were required to obtain pure products in relatively low yield.

In the active sites of the enzymes which recognise $ß$-lactam antibiotics ${ }^{15-19}$ there are a number of different functional groups close enough to the proposed incipient imine intermediate formed by ring opening to be able to react with this 'second trap' electrophilic centre. However, such nucleophiles could also attack the carbonyl carbon of the ester "leaving group” in 9-12 and so compete with that at the $\gamma$-lactam centre. In order to protect this site from nucleophilic attack a more sterically hindered ester was used. Subramanyam ${ }^{20}$ has reported the use of 2,6-disubstituted benzoates as leaving groups in compounds used to acylate the serine protease Human Leukocyte Elastase (HLE). The inhibition activity was dependent on the nature of the leaving group and the 2,6-disubstituents sterically prevented undesirable nucleophilic attack on the benzoyl carbonyl group. We therefore attempted to prepare the corresponding phthalimide derivative, 13. The 
acylation of the free hydroxy acid 5 with 2,6-dichlorobenzoyl chloride proved ineffective probably because of competing anhydride formation. The carboxylic acid residue was consequently protected as its methyl ester before acylation.

The first stage was the reaction of phthalimide with methyl glyoxylate to give Nphthalimido- $\alpha$-hydroxy-acetic acid methyl ester $14 .{ }^{1} \mathrm{H}$ NMR showed a characteristic methyl ester singlet at $3.77 \delta$ and the methine proton of these glyoxylates at $5.93 \delta$. Reaction of $\mathbf{1 4}$ with 2,6-dichlorobenzoyl chloride in pyridine to give $\mathrm{N}$-phthalimido- $\alpha$-2,6-dichlrobenzoyl-acetic acid methyl ester 15, the methine proton of the product now appearing at $7.24 \delta$. When $\mathrm{N}$ phthalimido- $\alpha$-2,6-dichlorobenzoyl-acetic acid methyl ester $\mathbf{1 5}$ was reacted with 1 equivalent of lithium iodide monohydrate in refluxing pyridine to give $\mathbf{1 3}$ in high yield. Having established a three step synthesis involving facile purifications and good overall yield, it was decided to try this method to make the phenylacetyl derivative 12, previously synthesised by the much lower yielding, but only two step synthesis, described earlier. The reaction of N-phthalimido- $\alpha$ hydroxy-acetic acid methyl ester $\mathbf{1 4}$ with phenylacetyl chloride gave the diester 16, but in low yield. The phenylacetylation of isatin- $\mathrm{N}-\alpha$-hydroxy-acetic acid methyl ester also gave poor yields compared with that obtained for the 2,6-dichloro derivative. The methine shifted from $5.93 \delta$ in the starting material $\mathbf{1 4}$ to $7.02 \delta$ in the product $\mathbf{1 6}$. However, when the lithium iodide demethylation of the methyl ester was attempted degradation occurred with the formation of phenylacetic acid as well as some unidentifiable products. The suggestion that lithium iodide is a specific reagent for ethyl and methyl esters only ${ }^{21}$ does not appear universal. Iodide attack on $\mathrm{N}$ phthalimido- $\alpha$-phenylacetyl-acetic acid methyl ester $\mathbf{1 6}$ apparently occurs at the more electron deficient methine carbon (Scheme 6), even though this site is more sterically hindered.

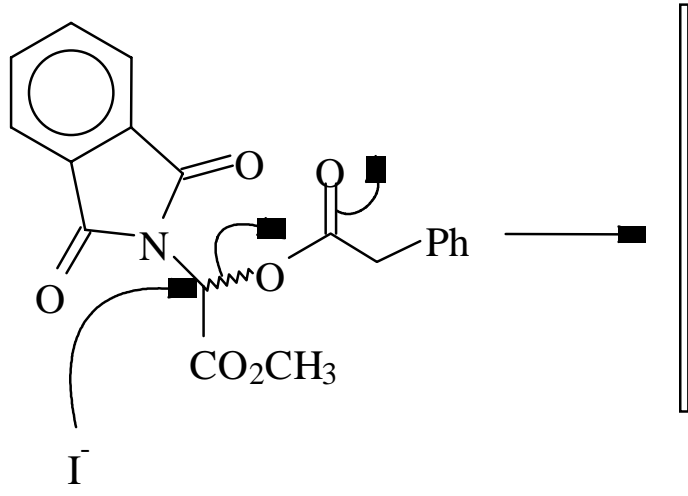

16

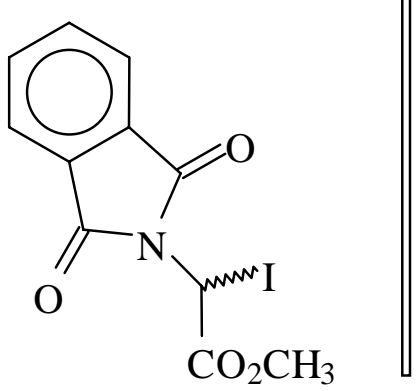<smiles>O=C(O)Cc1ccccc1</smiles>

Other products

\section{Scheme 6}


Presumably the 2,6-dichloro substituted compound 15 has this methine position shielded by the two bulky chloride groups preventing attack at this site. Attempts to selectively remove the methyl ester using pig liver esterase also failed as did other attempts to remove the carboxyl protecting ester group. Using a 4-nitrobenzyl ester protecting group for the carboxylic acid group, 17, followed by acylation of the hydroxyl group led to products $\mathbf{2 0}$ and $\mathbf{2 1}$ which also could not be selectively deprotected.

It was felt that more enzyme recognition needed to be incorporated into the structures such as an acylamino side chain commonly found in active penicillins. As well as improving the affinity of the substrate for the target enzymes, the reactivity of the amide bond would also be increased. (R/S)-Aspartic acid was $\mathrm{N}$-acylated using phenylacetyl chloride and then converted to the substituted succinic anhydride by the method of Mardle ${ }^{4}$ using acetic anhydride. When this anhydride was heated with ammonium carbonate only an $18 \%$ conversion to the imide was observed. A series of attempts to heat $\mathrm{N}$-acylated succinic acid with various nitrogen sources gave differing yields of the desired product, ie ammonia (8\%), ammonium carbonate (6\%) and finally urea (51\%). Now that an effective route was available to the imide stage, optically pure (S)-aspartic acid was acylated to give the diacid $\mathbf{3 0}$ followed by cyclisation to the imide $\mathbf{3 1}$ using urea (Scheme 7). The next step was the previously established reaction of $\mathbf{3 1}$ with glyoxylic acid which resulted in formation of $\mathbf{3 1}$ with a 50/50 mixture of disastereoisomers. Conversion of the hydroxy acid $\mathbf{3 2}$ to the chloro acid $\mathbf{3 3}$ by use of thionyl chloride gave a near equal mixture of the required diastereoisomeric product (Scheme 7). The $\alpha$-carbonyl group of isatin was converted to O-benzyloxime derivatives 27-29 to act also as a potential mimic of the $\mathrm{N}$-phenylacetamido side chain of benzylpenicillin, 1.

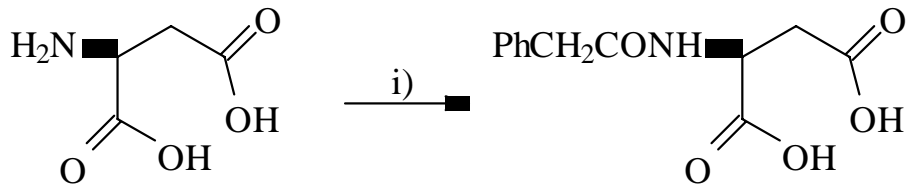

30

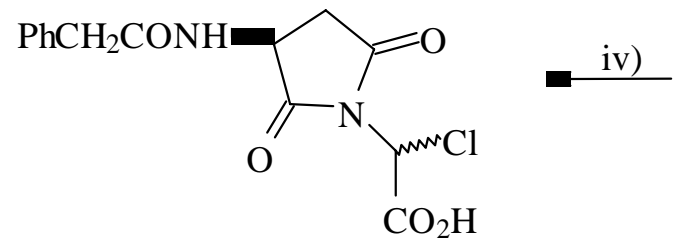

33

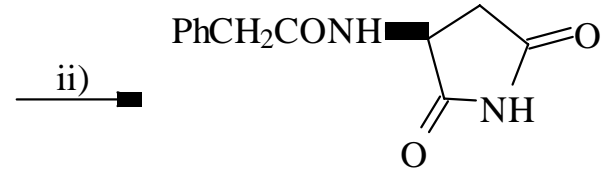

31
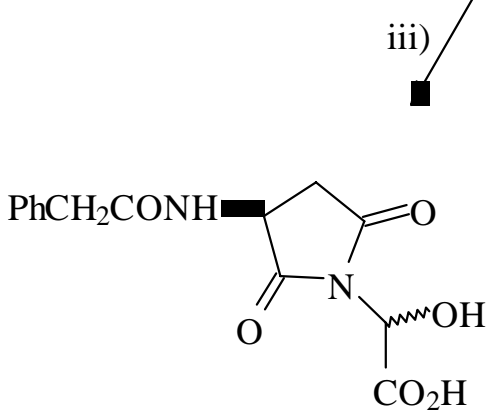

32

\section{Scheme 7}


Reagents and conditions: i) Phenylacetyl chloride, $\mathrm{NaOH}, 0^{\circ} \mathrm{C}$; ii) Urea, $170^{\circ} \mathrm{C}$; iii) Glyoxylic acid. $\mathrm{H}_{2} \mathrm{O}$, THF, reflux; iv) $\mathrm{SOCl}_{2}$, THF, $0^{\circ} \mathrm{C}, \mathrm{H}_{2} \mathrm{O}$

Chemical Reactivity - The second-order rate constants for the hydroxide-ion catalysed hydrolysis of the $\gamma$-lactams are given in Table 1. For comparison the second-order rate constant for the alkaline hydrolysis of benzyl penicillin is $0.15 \mathrm{M}^{-1} \mathrm{~s}^{-1}$ and so the $\gamma$-lactams have a similar or even greater reactivity indicating their suitability, on chemical grounds, as potential acylating agents of ß-lactamases and DD-peptidases. ${ }^{2}$ It has been suggested that the second order rate constant, $\mathrm{k}_{\mathrm{OH}}$, is a good indicator of enzyme acylating power and should have a value of 0.01 to $1.0 \mathrm{M}^{-1} \mathrm{~s}^{-1}$ to maximise inactivation with competing hydrolysis. ${ }^{22}$

Table 1.The second order rate constants, $\mathrm{k}_{\mathrm{OH}}$, for the hydroxide ion catalysed hydrolysis of the $\gamma$-lactams in water at $30^{\circ} \mathrm{C}$

\begin{tabular}{ll}
\hline Name & $\mathrm{k}_{\mathrm{OH}} / \mathrm{M}^{-1} \mathrm{~s}^{-1}$ \\
\hline n-Phthalimido- $\alpha$-chloro-acetic acid, 8 & 68.3 \\
n-Phthalimido- $\alpha$-acetoxyacetic acid, 10 & 33.5 \\
n-Phthalimido- $\alpha$-hydroxyacetic acid methyl ester, 14 & 22.1 \\
1,7-Dimethylisatin & 0.534 \\
n-Methylisatin & 0.465 \\
7-Methylisatin & 1.73 \\
Benzylpenicillin 1 & 0.15 \\
7-Methylisatin-N-acetic acid & 0.117 \\
\hline
\end{tabular}

Inhibition Studies - The $\gamma$-lactams were tested for inhibition ${ }^{23}$ of the $ß$-lactamase enzymes from Bacillus cereus 569/H class A and class B and the class C enzyme from Enterobacter cloacae P99 but no significant activity was found. The $\gamma$-lactams were also screened for antibacterial activity against a wide range of micro-organisms but they showed no significant activity up to a concentration of $128 \mu \mathrm{g} / \mathrm{cm}^{3}$.

\section{Experimental Section}

General Procedures. Melting points were determined on a Gallenkamp melting point apparatus and are uncorrected. $270 \mathrm{MHz}{ }^{1} \mathrm{H}$ and $67 \mathrm{MHz}{ }^{13} \mathrm{C}$ NMR were determined on a Bruker AC-270 spectrometer with tetramethylsilane as internal standard. All J values are given in Hz. IR spectra were recorded on a Perkin Elmer 1600 Series FTIR and FAB MS were performed by Swansea Mass Spectrometry Service and Zeneca Pharmaceuticals. All elemental analyses were performed by MEDAC Ltd., Brunel University. Fluka silica gel 60 was used for all chromatographic separations and thin layer chromatographic separations and thin layer chromatographic techniques used Merck silica gel $60 \quad \mathrm{~F}_{254}$ TLC plates. Ether refers to diethyl ether. Tetrahydrofuran was dried by distilling over lithium aluminium hydride under dry nitrogen. 
Dichloromethane was dried by passing it through a column of Grade I activated alumina into the reaction flask under argon.

Method A. $\boldsymbol{N}$-Succinimido- $\alpha$-hydroxyacetic acid (4) ${ }^{\mathbf{1 4}}$ Succinimide (50.0 g, 0.51 mol) was dissolved in THF $\left(300 \mathrm{~cm}^{3}\right)$ at room temperature with stirring. To this was added glyoxylic acid (50 wt\%) (74.80 g, $0.51 \mathrm{~mol}$ ) and the reaction mixture was heated to reflux for $3 \mathrm{~h}$. Evaporation to dryness under reduced pressure produced a yellow oil which eventually crystallised. This was recrystallised from ethyl acetate yielding 4 (52.95 g, 60\%) as white crystals. M. p. $140-141^{\circ} \mathrm{C}$ (lit. m.p. $140-141^{\circ} \mathrm{C}$ ) ${ }^{14}$ (Found: $\mathrm{C}, 4.71 ; \mathrm{H}, 4.0 ; \mathrm{N}, 8.0 . \mathrm{C}_{6} \mathrm{H}_{7} \mathrm{NO}_{5}$ requires $\mathrm{C}$, 41.6; H, 4.0; $\mathrm{N}$, 8.1\%); $v_{\max }(\mathrm{Nujol} \mathrm{mull}) / \mathrm{cm}^{-1} 3391,3048,1778,1740,1685,1455,1400,1285,1170,743 ; \delta_{\mathrm{H}}$ $\left(\mathrm{CD}_{3} \mathrm{OD}\right) 2.75\left(4 \mathrm{H}, \mathrm{s}, 2 \times \mathrm{CH}_{2}\right) 5.67(1 \mathrm{H}, \mathrm{s}, \mathrm{CH}) ; \mathrm{m} / \mathrm{z} 174(\mathrm{M}+\mathrm{H})^{+}, 156,128,100,82,72,56,44$ and 28.

$\boldsymbol{N}$-Phthalimido- $\alpha$-hydroxyacetic acid (5). Method A was used in the synthesis of $\mathbf{5}$ using phthalimide (10.0 g, $68.0 \mathrm{mmol}$ ), glyoxylic acid (50 wt\%) (30.20 g, $0.204 \mathrm{~mol}$ ) and THF $\left(200 \mathrm{~cm}^{3}\right)$ giving a cream solid on evaporation to dryness under reduced pressure. Recrystallisation from ethyl acetate yielded 5 (13.19 g, 88\%) as a white solid. M.p. $190-191^{\circ} \mathrm{C}$ (lit. m.p. 191-192 $\left.{ }^{\circ} \mathrm{C}\right)^{14}$ (Found: C, 54.0; H, 3.1; N, 6.4. $\mathrm{C}_{10} \mathrm{H}_{7} \mathrm{NO}_{5}$ requires C, 54.3; H, 3.2; N, $6.3 \%$ ); $v_{\max }$ (Nujol mull)/cm $\mathrm{cm}^{-1} 3340,1745,1709,1465,1379,1290,1173,1075,920,730 ; \delta_{H}$ (CD $\left.{ }_{3} \mathrm{OD}\right) 5.88$ (1H, s, $\left.\underline{\mathrm{CHOH}}\right) 7.90$ (4H, m. aryl,; m/z $221 \mathrm{M}^{+}$. 199, 175, 165, 153 and 147.

Isatin- $N$ - $\alpha$-hydroxyacetic acid (6). Method A was used in the synthesis of $\mathbf{6}$ using isatin (25.0 g, $0.170 \mathrm{~mol})$, glyoxylic acid monohydrate $(47.0 \mathrm{~g}, 0.612 \mathrm{~mol})$ and THF $\left(500 \mathrm{~cm}^{3}\right)$. Evaporation to dryness give a deep red oil which slowly crystallised. Recrystallisation using ethyl acetate afforded 6 (24.4 g, 65\%) as an orange powder. M.p. 167-168 ${ }^{\circ} \mathrm{C}$ (Found: C, 54.3; H, 3.2; N, 6.35. $\mathrm{C}_{10} \mathrm{H}_{7} \mathrm{NO}_{5}$ requires C, 54.3; H, 3.2: N, 6.3\%); $v_{\max }$ (Nujol ull/cm ${ }^{-1}$ 3443, 3019, 2927, 2855, 1736, 1726, 1607, 1467, 1353, 1216, 1191, 766; $\delta_{\mathrm{H}}\left(\mathrm{D}_{6} \mathrm{DMSO}\right) 6.01$ (1H, s, $\left.\underline{\mathrm{CHOH}}\right)$ $7.20(2 \mathrm{H}, \mathrm{m}, 2$ aryl protons in the 5 and 6 position of isatin) $7.77(2 \mathrm{H}, \mathrm{m}, 2$ aryl protons in the 4 and 7 positions of isatin); m/z (ESP+) $222(\mathrm{M}+\mathrm{H})^{+}$, 206, 204, 194, 176, 74 and 73.

Method B. $N$-Succinimido- $\alpha$-chloroacetic acid (7). N-Succinimido- $\alpha$-hydroxy-acetic acid 7 ( $2.00 \mathrm{~g}, 12.0 \mathrm{mmol}$ ) was dissolved in dry THF $\left(50 \mathrm{~cm}^{3}\right)$ with stirring at room temperature under nitrogen. The solution was cooled to $0^{\circ} \mathrm{C}$ before thionyl chloride ( $3.44 \mathrm{~g}, 29.0 \mathrm{mmol}$ ) was added dropwise. Evolution of an acidic gas was observed. The reaction mixture was allowed to warm to room temperature overnight. Ice (10 g) was added and the mixture stirred for a further $3 \mathrm{~h}$. The solution was extracted using ethyl acetate $\left(3 \times 50 \mathrm{~cm}^{3}\right)$, the organics dried $\left(\mathrm{MgSO}_{4}\right)$, filtered and evaporated to give a viscous brown oil. Trituration of this with dichloromethane yielded 6 (0.68 g, 28\%) as a white powder. M.p. $182-184^{\circ} \mathrm{C}$ (Found: C, 37.55,; H, 3.2; N, 7.1. $\mathrm{C}_{6} \mathrm{H}_{6} \mathrm{ClNO}_{4}$ requires C, 37.6; H, 3.2; N, 7.3\%); $v_{\max }\left(\mathrm{Nujol}\right.$ mull)/cm $\mathrm{cm}^{-1} 3053,1788,1749,1688,1460,1413$, 1396, 1285, 1173, 745; $\delta_{\mathrm{H}}\left(\mathrm{Cd}_{3} \mathrm{OD}\right) 2.90\left(4 \mathrm{H}, \mathrm{s}, 2 \mathrm{x} \mathrm{CH}_{2}\right) 6.42(1 \mathrm{H}, \mathrm{s}, \mathrm{CHCl}) ; \mathrm{m} / \mathrm{z} 192(\mathrm{M}-\mathrm{H})^{-}$ $\left(\mathrm{Cl}^{35}\right), 155,146$ and 143.

$\boldsymbol{N}$-Phthalimido- $\alpha$-chloroacetic acid (8). Method B was used in the synthesis of 8 using $\mathrm{N}$ phthalimido- $\alpha$-hydroxy-acetic acid 5 (2.00 g, $9.0 \mathrm{mmol}$ ), thionyl chloride (3.37 g, $28.0 \mathrm{mmol}$ ) 
and dry THF $\left(100 \mathrm{~cm}^{3}\right)$. Trituration of the resultant cream solid with hot dichloromethane yielded 8 (0.30 g, $13 \%$ ) as a white powder. M.p. $146-148^{\circ} \mathrm{C}$ (Found: C, 49.7; H, 2.6; N, 5.7. $\mathrm{C}_{10} \mathrm{H}_{6} \mathrm{ClNO}_{4}$ requires $\mathrm{C}, 50.1 ; \mathrm{H}, 2.5 ; \mathrm{N}, 5.85 \%$ ); $v_{\max }\left(\mathrm{Nujol}\right.$ mull)/ $/ \mathrm{cm}^{-1} 3278,1788,1750,1463$, $1277,1238,1198,1174,1076,918,720 ; \delta_{\mathrm{H}}\left(\mathrm{CD}_{3} \mathrm{OD}\right) 6.70(1 \mathrm{H}, \mathrm{s}, \underline{\mathrm{CHCl}}) 7.98(4 \mathrm{H}, \mathrm{m}, \mathrm{aryl}) ; \mathrm{m} / \mathrm{z}$ $240(\mathrm{M}-\mathrm{H})^{-}\left(\mathrm{Cl}^{37}\right), 238(\mathrm{M}-\mathrm{H})^{-}\left(\mathrm{Cl}^{35}\right), 219,204,194,159$ and 146.

Isatin- $N$ - $\alpha$-chloroacetic acid (19). Method B was used in the synthesis of 19 using isatin- $\mathrm{N}-\alpha-$ hydroxy-acetic acid 6 (10.0 g, $45.0 \mathrm{mmol})$, thionyl chloride (16.15 g, $0.136 \mathrm{~mol})$, a catalytic amount of DMF $\left(0.5 \mathrm{~cm}^{3}\right)$ and dry $\mathrm{CH}_{2} \mathrm{Cl}_{2}\left(150 \mathrm{~cm}^{3}\right)$. The solution was evaporated to dryness and re-dissolved in THF $\left(150 \mathrm{~cm}^{3}\right)$. The mixture was stirred and cooled to $0^{\circ} \mathrm{C}$ before the addition of ice (50g). The evolution of gases was observed and this stopped after $2 \mathrm{~h}$. The homogenous reaction mixture was again evaporated under reduced pressure until all THF had been removed and the aqueous layer extracted with ethyl acetate $\left(3 \times 75 \mathrm{~cm}^{3}\right)$. The combined organics were dried using $\mathrm{MgSO}_{4}$, filtered and reduced to leave an orange oil. This was dissolved in a small amount of dichloromethane and hexane was added until the product crystallised and was collected by filtration. The first crop of the reaction gave 19 (1.30 g, 12\%) as an orange powder. M.p. $150-151^{\circ} \mathrm{C}$ (Found: C, 50.1; H, 2.5; N, 5.85. $\mathrm{C}_{10} \mathrm{H}_{6} \mathrm{ClNO}_{5}$ requires $\mathrm{C}$, 50.1; H, 2.5; N, 5.85\%); $v_{\max }\left(\mathrm{CHCl}_{3}\right) / \mathrm{cm}^{-1} 3446,3020,2927,2855,2400,1747,1727,1608$, 1471, 1380, 1352, 1216, 1121, 758; $\delta_{\mathrm{H}}\left(\mathrm{D}_{6} \mathrm{DMSO}\right) 7.18(1 \mathrm{H}, \mathrm{s}, \underline{\mathrm{CHCl}}) 7.20(2 \mathrm{H}, \mathrm{m}, 2$ aryl protons in the 5 and 6 positions of isatin) $7.78(2 \mathrm{H}, \mathrm{m}, 2$ aryl protons in the 4 and 7 position of isatin); $\mathrm{m} / \mathrm{z}(\mathrm{FAB}+) 241(\mathrm{M}+\mathrm{H})^{+}$. 239, 223, 222, 206, 204, 194, 176, 148, 146, 130, 116, 84, 83, 74, 69 and 64.

Method C. $N$-Succinimido- $\alpha$-acetoxyacetic acid (9). $N$-Succinimido- $\alpha$-hydroxy-acetic acid 3 $(2.00 \mathrm{~g}, 12.0 \mathrm{mmol})$ was dissolved in pyridine $\left(10 \mathrm{~cm}^{3}\right)$ at $0^{\circ} \mathrm{C}$ with stirring under nitrogen. Acetyl chloride $(1.00 \mathrm{~g}, 13.0 \mathrm{mmol})$ was added dropwise to the solution over 5 mins. The reaction was left for $4 \mathrm{~h}$. and during this time a brown precipitate was observed. After evaporation to dryness the resultant brown solid was dissolved in a 50/50 ethyl acetate/2M hydrochloric acid mix $\left(100 \mathrm{~cm}^{3}\right)$. The aqueous was extracted with ethyl acetate $\left(3 \mathrm{x} 50 \mathrm{~cm}^{3}\right)$ and the combined organics dried using $\mathrm{Na}_{2} \mathrm{SO}_{4}$, filtered and evaporated to give a crude yellow oil. Silica gel chromatrography (50/50 ethyl acetate/hexane) yielded 9 (1.38 g, 56\%) as a colourless oil which later crystallised. M.p. $120-122^{\circ} \mathrm{C}$ (Found: $\mathrm{C}, 44.2 ; \mathrm{H}, 4.4 ; \mathrm{N}, 6.5 . \mathrm{C}_{8} \mathrm{H}_{9} \mathrm{NO}_{6}$ requires C, 44.6; H, 4.2; N, 6.5\%); $v_{\max }$ (Nujol mull)/ $/ \mathrm{cm}^{-1} 3284,1785,1733,1727,1451,1420,1374$, 1248, 1190, 1049, 741; $\delta_{\mathrm{H}}\left(\mathrm{CD}_{3} \mathrm{OD}\right) 2.17\left(3 \mathrm{H}, \mathrm{s}, \mathrm{CH}_{3}\right) 2.85\left(4 \mathrm{H}, \mathrm{s}, 2 \times \mathrm{CH}_{2}\right) 6.77(1 \mathrm{H}, \mathrm{s}, \mathrm{CH})$; $\mathrm{m} / \mathrm{z} 214(\mathrm{M}-\mathrm{H})^{-}, 165,151$ and 143.

$\mathbf{N}$-Phthalimido- $\alpha$-acetoxyacetic acid (10). Method C was used in the synthesis of $\mathbf{1 0}$ using $\mathrm{N}$ phthalimido- $\alpha$-hydroxy-acetic acid 5 (2.00 g, $9.0 \mathrm{mmol})$, acetyl chloride $(0.78 \mathrm{~g}, 10.0 \mathrm{mmol})$ and pyridine $\left(10 \mathrm{~cm}^{3}\right)$. A further $10 \mathrm{~cm}^{3}$ of pyridine was added to help solubilise the thick suspension formed and the reaction left overnight. Recrystallisation of the crude yellow solid from ethyl acetate afforded $10(0.72 \mathrm{~g}, 30 \%)$ as a white solid. M.p. $186-188^{\circ} \mathrm{C}$ (Found: C, 54.3; H, 3.5; N, 5.1. $\mathrm{C}_{12} \mathrm{H}_{9} \mathrm{NO}_{6}$ requires C, 54.7; H, 3.4; N, 5.3\%); $v_{\max }(\mathrm{Nujol} / \mathrm{mull}) / \mathrm{cm}^{-1} 3292,1787,1736$, 
1463, 1377, 1265, 1195, 1122, 1053, 745; $\delta_{\mathrm{H}}\left(\mathrm{CD}_{3} \mathrm{OD}\right) 2.16\left(3 \mathrm{H}, \mathrm{s}, \mathrm{CH}_{3}\right) 6.94(1 \mathrm{H}, \mathrm{s}, \underline{\mathrm{ChO}}) 7.90$ (4H, m, aryl); m/z 262 (M-H)', 188, 146 and 122.

$\boldsymbol{N}$-Succinimido- $\alpha$-phenylacetoxyacetic acid (11). Method $\mathrm{C}$ was used in the synthesis of 11 using N-succinimido- $\alpha$-hydroxy-acetic acid 4 (2.00 g, $12.0 \mathrm{mmol})$, phenylacetyl chloride (3.58 $\mathrm{g}, 23.0 \mathrm{mmol}$ ) and pyridine $\left(25 \mathrm{~cm}^{3}\right)$. Trituration of the crude brown solid with dichloromethane yielded 11 (1.39 g, 41\%) as a white powder. M.p. $149-151^{\circ} \mathrm{C}$ (Found: C, 58.0; $\mathrm{H}$, 4.6; N, 4.5. $\mathrm{C}_{14} \mathrm{H}_{13} \mathrm{NO}_{6}$ requires C, 57.7; H, 4.5; N, 4.8\%); $v_{\max }$ (Nujol mull)/cm ${ }^{-1} 1787,1751$, 1682, 1496, 1459, 1377, 1233, 1189, 1117, 1055, 915, 721; $\delta_{\mathrm{H}}\left(\mathrm{CD}_{3} \mathrm{OD}\right) 2.77\left(4 \mathrm{H}, \mathrm{s}, 2\right.$ x $\left.\mathrm{CH}_{2}\right)$ 3.75 (2H, s, $\left.\underline{\mathrm{CH}}_{2} \mathrm{Ph}\right) 6.74$ (1H, s, CHO) 7.27 (5H, m, Ph); m/z 290 (M-H)', 247, 227, 172, 155, 135 and 111.

$N$-Phthalimido- $\alpha$-phenylacetoxyacetic acid (12). Method $\mathrm{C}$ was used in the synthesis of 12 using N-phthalimido- $\alpha$-hydroxy-acetic acid 5 (4.59 g, $21.0 \mathrm{mmol}$ ), phenylacetyl chloride (6.42 g, $42.0 \mathrm{mmol}$ ) and pyridine $\left(30 \mathrm{~cm}^{3}\right)$. Trituration of the crude brown solid with hot 60.80 petroleum ether removed excess phenylacetic acid and silica gel chromatography (gradient elution 25\% ethyl acetate/hexane to $100 \%$ ethyl acetate) yielded 12 (0.94 g, 13\%) as a white powder. M.p. 123-125 ${ }^{\circ} \mathrm{C}$ (Found: C, 63.4; H, 3.9; N, 3.9. $\mathrm{C}_{18} \mathrm{H}_{13} \mathrm{NO}_{6}$ requires $\mathrm{C}$, 63.7; H, 3.9; N, 4.1\%); $v_{\max }$ (Nujol mull)/cm ${ }^{-1} 1789,1730,1726,1385,1265,1188,1132,1030,741 ; \delta_{\mathrm{H}}\left(\mathrm{CD}_{3} \mathrm{OD}\right) 3.78(2 \mathrm{H}$, s, $\left.\mathrm{CH}_{2}\right) 6.95(1 \mathrm{H}, \mathrm{s}, \mathrm{CHO}) 7.23\left(5 \mathrm{H}, \mathrm{m}, \mathrm{CH}_{2} \underline{\mathrm{Ph}}\right) 7.88(4 \mathrm{H}, \mathrm{m}, \operatorname{aryl}) ; \mathrm{m} / \mathrm{z} 340(\mathrm{M}+\mathrm{H})^{+}, 294,277$, 204, 177, 171, 167, 157, 148, 137, 118 and 105.

$N$-Phthalimido- $\alpha$-hydroxyacetic acid methyl ester (14). Phthalimide (20.0 g, 0.136 mol) was dissolved in THF $\left(150 \mathrm{~cm}^{3}\right)$ at room temperature with stirring. To this was added methyl glyoxylate (17.94 g, $0.204 \mathrm{~mol}$ ) and the reaction mixture was heated to reflux for $2 \mathrm{~h}$. Evaporation to dryness under reduced pressure produced a white semi-solid. This was recrystallised from ethyl acetate yielding 14 (19.22 g, 60\%) as a white solid. M.p. $132-133^{\circ} \mathrm{C}$ (Found: C, 56.05; H, 3.8; N, 6.0. $\mathrm{C}_{11} \mathrm{H}_{9} \mathrm{NO}_{5}$ requires $\mathrm{C}, 56.1 ; \mathrm{H}, 3.8 ; \mathrm{N}, 5.95 \%$ ); $v_{\max }$ (Nujol mull $) / \mathrm{cm}^{-1} 3250,1784,1760,1460,1378,1250,1198,1120,722 ; \delta_{\mathrm{H}}\left(\mathrm{CD}_{3} \mathrm{OD}\right) 3.77\left(3 \mathrm{H}, \mathrm{s}, \mathrm{CH}_{3}\right)$ 5.93 (1H, s, $\underline{\mathrm{CHOH}}) 7.84$ (4H, m, aryl); m/z 234 (M-H)', 212, 188, 153, 147 and 90.

Method D: $N$-Phthalimido- $\alpha$-2,6-dichlorobenzoxyacetic acid methyl ester (15). $N$ Phthalimido- $\alpha$-hydroxy-acetic acid methyl ester 14 (1.0 g, $4.3 \mathrm{mmol})$ was dissolved in pyridine $\left(10 \mathrm{~cm}^{3}\right)$ at $0^{\circ} \mathrm{C}$ with stirring under nitrogen. To this was added dropwise 2,6-dichlorobenzoyl chloride (1.34 g, $6.4 \mathrm{mmol})$ and a colour change from yellow to brown was observed followed by the appearance of a white precipitate. The reaction mixture was allowed to warm to room temperature over $3 \mathrm{~h}$. The mixture was evaporated to dryness then dissolved in a 50/50 ethyl acetate/2M hydrochloric acid $\operatorname{mix}\left(100 \mathrm{~cm}^{3}\right)$. The aqueous was extracted with ethyl acetate $(3 \mathrm{x}$ $50 \mathrm{~cm}^{3}$ ) and the combined organics washed with saturated sodium hydrogen carbonate solution. The organics were dried with $\mathrm{Na}_{2} \mathrm{SO}_{4}$, filtered and evaporated to give a dark brown oil. Silica gel chromatography (10\% ethyl acetate/petroleum ether (60/80) afforded 15 (1.16 g, 67\%) as a white solid. M.p. 152-153 ${ }^{\circ} \mathrm{C}$ (Found: C, 52.8; H, 2.7; N, 3.5. $\mathrm{C}_{18} \mathrm{H}_{11} \mathrm{Cl}_{2} \mathrm{NO}_{6}$ requires C, 52.9; H, 2.7; N, $3.4 \%) ; v_{\max }(\mathrm{Nujol} \mathrm{mull}) / \mathrm{cm}^{-1} 1769,1760,1709,1455,1370,1256,1190,1149,1080,722 ; \delta_{\mathrm{H}}$ $\left(\mathrm{CDCl}_{3}\right) 3.91\left(3 \mathrm{H}, \mathrm{s}, \mathrm{CH}_{3}\right) 7.24(1 \mathrm{H}, \mathrm{s}, \underline{\mathrm{CHO}}) 7.30(3 \mathrm{H}, \mathrm{m}$, benzoyl aromatics) $7.85(4 \mathrm{H}, \mathrm{m}$. 
Phthalimide aromatics); $\delta_{\mathrm{C}}\left(\mathrm{CDCl}_{3}\right) 53.86\left(\mathrm{Ch}_{3}\right) 69.25$ (NCHO) 124.30 (para carbon of benzoyl) 127.96 ( $2 \times \mathrm{ClC} \underline{\mathrm{CH}}) 131.38$ ( $2 \mathrm{x} \mathrm{C}(\mathrm{O}) \underline{\mathrm{C}}$ of imide) 131.50 ( $2 \mathrm{x}$ meta aryl of imide) 131.74

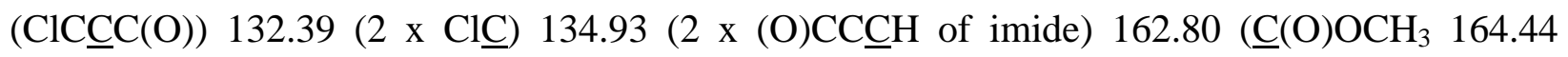
(ClCCE(O)) 165.58 (2 x NC(O) of imide) m/z $408(\mathrm{M}+\mathrm{H})^{+}, 355,341,263,249,235,218$ and 190.

$N$-Phthalimido- $\alpha$-2,6-dichlorobenzoxyacetic acid (13). N-Phthalimido- $\alpha$-2,6-dichlorobenzoylacetic acid methyl ester $15(0.60 \mathrm{~g}, 1.5 \mathrm{mmol})$ and lithium iodide monohydrate $(0.224 \mathrm{~g}$, $1.5 \mathrm{mmol})$ were dissolved in pyridine $\left(10 \mathrm{~cm}^{3}\right)$ under nitrogen and the solution heated to reflux for $24 \mathrm{~h}$. The mixture was evaporated to dryness and taken up into ethyl acetate $\left(50 \mathrm{~cm}^{3}\right)$ then washed with saturated sodium hydrogen carbonate solution $\left(50 \mathrm{~cm}^{3}\right)$. The aqueous was extracted using ethyl acetate $\left(3 \times 50 \mathrm{~cm}^{3}\right)$ then taken to $\mathrm{pH} 2$ with $2 \mathrm{M}$ hydrochloric acid. The aqueous was re-extracted with ehtyl acetate $\left(3 \times 50 \mathrm{~cm}^{3}\right.$ ) and the combined organics dried using $\mathrm{MgSO}_{4}$, filtered and evaporated to dryness to give a yellow solid. This was triturated with dichloromethane then ether to give 12 (0.388 g, 67\%) as a white solid. M.p. $181-183^{\circ} \mathrm{C}$ (Found: C, 51.6; H, 2.35; N, 3.5. $\mathrm{C}_{17} \mathrm{H}_{9} \mathrm{Cl}_{2} \mathrm{NO}_{6}$ requires C, 51.8; H, 2.3; N, 3.55\%); $v_{\max }(\mathrm{Nujol} \mathrm{mull}) / \mathrm{cm}^{-}$

1 1767, 1762, 1709, 1464, 1377, 1315, 1256, 1198, 1130, 1050, 875, 781, 723; $\delta_{\mathrm{H}}\left(\mathrm{CD}_{3} \mathrm{OD}\right) 7.20$ (1H, s, $\underline{\mathrm{CHO}} 7.42$ (3H, s, benzoyl aromatics) $7.83(4 \mathrm{H}, \mathrm{m}$, phthalimide aromatics); m/z 394 $(\mathrm{M}+\mathrm{H})^{+}, 204,185,177,173,160,148,139,133,123$ and 105.

$\boldsymbol{N}$-Phthalimido- $\alpha$-phenylacetoxyacetic acid methyl ester (16). Method D was used in the synthesis of 16 using N-phthalimido- $\alpha$-hydroxy-acetic acid methyl ester 14 (3.0 g, $13.0 \mathrm{mmol}$ ), pyridine $\left(25 \mathrm{~cm}^{3}\right)$ and phenylacetyl chloride $(5.91 \mathrm{~g}, 38.0 \mathrm{mmol})$ and the appearance of a white precipitate was observed. Silica gel chromatography $\left(\mathrm{CH}_{2} \mathrm{Cl}_{2}\right)$ afforded $15(1.27 \mathrm{~g}, 28 \%)$ as a white solid. M.p. $72-73^{\circ} \mathrm{C}$ (Found: C, 64.2; H, 4.3; N, 3.9. $\mathrm{C}_{19} \mathrm{H}_{15} \mathrm{NO}_{6}$ requires C, 64.5; H, 4.25; $\mathrm{N}, 4.0 \%) ; v_{\max }\left(\right.$ Nujol mull)/(m $\mathrm{cm}^{-1} 1785,1760,1729,1457,1380,1246,1188,1144,738 ; \delta_{\mathrm{H}}$ $\left(\mathrm{CDCl}_{3}\right) 3.81\left(3 \mathrm{H}, \mathrm{s}, \mathrm{CH}_{3}\right) 3.77\left(2 \mathrm{H}, \mathrm{q}, J_{\mathrm{AB}} 15.8\right.$ and 15.8, $\left.\underline{\mathrm{CH}_{2}} \mathrm{Ph}\right) 7.02(1 \mathrm{H}, \mathrm{s}, \underline{\mathrm{CHO}}) 7.29(5 \mathrm{H}$, m, $\left.\mathrm{CH}_{2} \underline{\mathrm{Ph}}\right) 7.85$ (4H, m, phthalimide aromatics); m/z $354(\mathrm{M}+\mathrm{H})^{+}, 308,291,218,191,171,162$ and 132.

Attempted de-esterification of $\boldsymbol{N}$-phthalimide- $\alpha$-phenylacetoxyacetic acid methyl ester (15). N-Phthalimido- $\alpha$-phenylacetyl-acetic acid methyl ester 16 (0.75 g, $2.1 \mathrm{mmol})$ and lithium iodide monohydrate $(0.355 \mathrm{~g}, 2.3 \mathrm{mmol})$ were dissolved in pyridine $\left(10 \mathrm{~cm}^{3}\right)$ under nitrogen and the solution heated to reflux for $24 \mathrm{~h}$. The ixture was evaporated to dryness and taken up into ethyl acetate $\left(50 \mathrm{~cm}^{3}\right)$ then washed with saturated sodium hydrogen carbonate solution $\left(50 \mathrm{~cm}^{3}\right)$. The aqueous was extrcted using ethyl acetate $\left(3 \times 50 \mathrm{~cm}^{3}\right)$ then taken to $\mathrm{pH} 2$ with $2 \mathrm{M}$ hydrochloric acid. The aqueous was re-extracted with ethyl cetate $\left(3 \times 50 \mathrm{~cm}^{3}\right)$ and the combined organics dried using $\mathrm{MgSO}_{4}$, filtered and evaporated to dryness to give a brown solid. Analysis of the crude reaction material revealed by-product phenylacetic acid and further degradation products of N-Phthalimido- $\alpha$-iodo-acetic acid methyl ester.

Isatin- $N$ - $\alpha$-hydroxyacetic acid 4-nitrobenzyl ester (17). p-Nitrobenzyl glyoxylate (10.0 g, $44.1 \mathrm{mmol})$ was dissolved in toluene $\left(150 \mathrm{~cm}^{3}\right)$ and the solution refluxed for $1 \mathrm{~h}$. with a Dean and Stark apparatus attached. After cooling, isatin (3.23 g, $22.0 \mathrm{mmol}$ ) was added and the 
solution refluxed overnight. On cooling with ice, a precipitate appeared which when filtered gave 17 (5.83 g, 74\%) as an orange crystalline solid. M.p. $160-163^{\circ} \mathrm{C}$ (Found: C, 57.1; H, 3.4; N, 8.1. $\mathrm{C}_{17} \mathrm{H}_{12} \mathrm{~N}_{2} \mathrm{O}_{7}$ requires C, 57.3; H, 3.4; N, 6.9\%); $v_{\max }$ (Nujol mull)/cm ${ }^{-1} 3280,1734,1620,1520$, 1350; $\delta_{\mathrm{H}}\left(\mathrm{D}_{6} \mathrm{DMSO}\right) 5.40\left(2 \mathrm{H}, \mathrm{s}, \mathrm{CH}_{2}\right) 6.25$ (1H, d, $J$ 6.4, NCH 7.12-7.62 (4H, m, aryl) 7.54 (2H, d, $J$ 8.8, para aryl) 8.17 (2H, d, $J$ 8.8, para aryl).

Isatin- $N$ - $\alpha$-acetoxyacetic acid 4-nitrobenzyl ester (20). Method D was used for the synthesis of 20 using isatin- $\mathrm{N}$ - $\alpha$-hydroxy-acetic acid 4-nitrobenzyl ester 17 (2.0 g, 5.62 mmol) pyridine $\left(10 \mathrm{~cm}^{3}\right)$ and acetyl chloride $(0.49 \mathrm{~g}, 6.18 \mathrm{mmol})$. After reaction for $3 \mathrm{~h}$. the solution was then poured onto ice water $\left(100 \mathrm{~cm}^{3}\right)$ and the resultant precipiate filtered, washed with cold water and dried to give 20 (1.82 g, 54\%) as a dark yellow powder. M.p. 138-140 ${ }^{\circ} \mathrm{C}$ (Found: C, 57.4; H, 3.6; $\mathrm{N}, 7.1 . \mathrm{C}_{19} \mathrm{H}_{14} \mathrm{~N}_{2} \mathrm{O}_{8}$ requires C, 57.3; H, 3.5; N, 7.0\%); $v_{\max }$ (Nujol mull)/cm ${ }^{-1} 1770,1740,1620$, 1520; $\delta_{\mathrm{H}}\left(\mathrm{D}_{6} \mathrm{DMSO}\right) 2.15\left(3 \mathrm{H}, \mathrm{s}, \mathrm{CH}_{3}\right) 5.40\left(2 \mathrm{H}, \mathrm{s}, \mathrm{CH}_{2}\right) 7.10-7.25(2 \mathrm{H}, \mathrm{m}$, aryl) $7.28(1 \mathrm{H}, \mathrm{s}, \mathrm{N}-$ CH) 7.52 (2H, d, $J$ 8.6, para aryl) 7.60-7.70 (2H, m, aryl) 8.15 (2H, d, $J$ 8.6, para aryl); m/z 399 $(\mathrm{M}+\mathrm{H})^{+}, 398$ and 339 .

Isatin- $N$ - $\alpha$-2,6-dichlorobenzoxyacetic acid 4-nitrobenzyl ester (21). Method D was used in the preparation of $\mathbf{2 1}$ using isatin-N- $\alpha$-hydroxy-acetic acid 4-nitrobenzyl ester 17 (2.0 g, $5.62 \mathrm{mmol})$, pyridine $\left(10 \mathrm{~cm}^{3}\right)$ and 2,6-dichlorobenzoyl chloride $(1.29 \mathrm{~g}, 6.18 \mathrm{mmol})$. The reaction afforded 21 (2.36 g, 52\%) as a cream powder. M.p. $105-106^{\circ} \mathrm{C} ; v_{\max }\left(\mathrm{Nujol} / \mathrm{mull} / \mathrm{cm}^{-1}\right.$ 1776, 1736, 1610; $\delta_{\mathrm{H}}\left(\mathrm{D}_{6} \mathrm{DMSO}\right) 5.50\left(2 \mathrm{H}, \mathrm{s}, \mathrm{CH}_{2}\right)$ 7.25-7.28 (2H, m, aryl) 7.55-7.80 (8H, m, aryl and $\mathrm{NCH}) 8.20$ (2H, d, $J$ 8.7, para aryl); m/z $530(\mathrm{M})^{+}$.

(R/S)-N-Phenylacetylaspartic acid Phenylacetyl chloride (58.07 g, 0.376 mol), 4M sodium hydroxide solution $\left(92.5 \mathrm{~cm}^{3}\right)$, (R/S)-aspartic acid (50.0 g, $0.376 \mathrm{~mol}$ ) and 2M sodium hydroxide solution $\left(375 \mathrm{~cm}^{3}\right.$ ) were used. The reaction yielded the product $(75.05 \mathrm{~g}, 80 \%)$ as a white crysalline solid. M.p. $116-117^{\circ} \mathrm{C}$ (lit m.p. $117^{\circ} \mathrm{C}$ ) (Found: C, 57.0; H, 5.1; N, 5.6. $\mathrm{C}_{12} \mathrm{H}_{13} \mathrm{NO}_{5}$ requires C, 57.4; H, 5.2; N, 5.6\%); $v_{\max }\left(\right.$ Nujol mull)/cm $\mathrm{cm}^{-1} 3409$, 3330, 2960, 1734, 1709, 1646, 1539, 1457, 1344, 1283, 1234, 1191, 1154, 959, 734; $\delta_{\mathrm{H}}\left(\mathrm{CD}_{3} \mathrm{OD}\right) 2.92\left(2 \mathrm{H}\right.$, dd, $J_{\mathrm{ABX}} 6.5$ and 5.5, $\left.\underline{\mathrm{CH}_{2}} \mathrm{CH}\right) 3.57$ (2H, s, H-5) $4.74\left(1 \mathrm{H}, \mathrm{dd}, J_{\mathrm{ABX}} 6.5\right.$ and 5.5, $\left.\mathrm{CH}_{2} \underline{\mathrm{CH}}\right) 7.29(5 \mathrm{H}, \mathrm{m}, \mathrm{aryl}) ; \mathrm{m} / \mathrm{z}$ $(\mathrm{ESP}+) 251(\mathrm{M}+\mathrm{H})^{+}, 234,134,87,55$.

(R/S)-N-Phenylacetylaspartic anhydride (R/S)-N-Phenylacetylaspartic acid (50.0 g, 0.20 mol) and acetic anhydride $\left(150 \mathrm{~cm}^{3}\right)$ were used as described. ${ }^{4}$. The product $(30.62 \mathrm{~g}, 66 \%)$ was a white crystalline solid. M.p. $160-162^{\circ} \mathrm{C}$ (lit. m.p. $\left.162^{\circ} \mathrm{C}\right)^{4}$ (Found: C, 62.0; H, 4.8; N, 6.0. $\mathrm{C}_{12} \mathrm{H}_{11} \mathrm{NO}_{4}$ requires C, 61.8; $\mathrm{H}, 4.7 ; \mathrm{N}, 6.0 \%$ ); $v_{\max }\left(\mathrm{Nujol}\right.$ mull)/cm ${ }^{-1} 3331,2918,2853,1851$, 1824, 1780, 1652, 1525, 1456, 1231, 1196, 1068, 974, 904, 737; $\delta_{\mathrm{H}}\left(\mathrm{D}_{6} \mathrm{DMSO}\right) 2.79$ (1H, dd, $J_{\mathrm{ABX}} 18.4$ and 5.7, $\left.\mathrm{CHCH}_{2}\right) 3.22\left(1 \mathrm{H}\right.$, dd, $J_{\mathrm{ABX}} 18.4$ and 10.1, $\left.\underline{\mathrm{CHCH}}_{2}\right) 3.50$ (2H, s, $\left.\underline{\mathrm{CH}}_{2} \mathrm{Ph}\right) 4.65$ $\left(1 \mathrm{H}, \mathrm{m}, \underline{\left.\mathrm{CHCH}_{2}\right)} 7.27\right.$ (5H, m, aryl) $8.96(1 \mathrm{H}, \mathrm{d}, J$ 7.1, $\mathrm{NH})$.

\section{(R/S)-N-Phenylacetylaspartimide}

Method 1 (R/S)-N-Phenylacetylaspartic anhydride (24.83g, $0.107 \mathrm{~mol}$ ) was added to finely ground ammonium carbonate (5.63g, $59.0 \mathrm{mmol}$ ), mixed thoroughly and heated to $180^{\circ} \mathrm{C}$ for $1 \mathrm{~h}$. During this time, the mixture turned partially molten and more ammonium carbonate (5.63g, 
59.0 mmol) was added until no further gases evolded. The mixture turned from colourless to brown and water droplets were observed condensing on the apparatus. The reaction was allowed to cool and then dissolved in a 50/50 ethyl acetate/THF mix $\left(250 \mathrm{~cm}^{3}\right)$ and water $\left(250 \mathrm{~cm}^{3}\right)$. The aqueous layer was extracted using ethyl acetate $\left(3 \times 150 \mathrm{~cm}^{3}\right)$, the combined organics were then washed with saturated sodium hydrogen carbonate solution $\left(150 \mathrm{~cm}^{3}\right)$, brine $\left(150 \mathrm{~cm}^{3}\right)$ and dried with $\mathrm{Na}_{2} \mathrm{SO}_{4}$. Filtration and evaporation gave a brown solid which when washed with cold methanol afforded the product $\left(4.59 \mathrm{~g}, 18 \%\right.$ ) as a white powder. M.p. $196-198^{\circ} \mathrm{C}$ (Found: C, 61.7; H, 5.1; N, 12.1. $\mathrm{C}_{12} \mathrm{H}_{12} \mathrm{~N}_{2} \mathrm{O}_{3}$ requires $\mathrm{C}, 62.1 ; \mathrm{H}, 5.2 ; \mathrm{N}, 12.1 \%$ ); $v_{\max }$ (Nujol mull)/cm ${ }^{-1}$ 3299, 3172, 2925, 2854, 1733, 1722, 1640, 1544, 1464, 1377, 1211, 1199, 1177, 761; $\delta_{\mathrm{H}}$ $\left(\mathrm{CD}_{3} \mathrm{OD}\right)$ 2.39-2.50 (1H, dd, $J_{\mathrm{ABX}} 17.6$ and 5.4, $\left.\mathrm{CHCH}_{2}\right)$ 2.79-2.93 (1H, $J_{\mathrm{ABX}} 17.6$ and 9.5, $\left.\underline{\mathrm{CH}}_{2}\right)$ 3.55 (2H, s, $\left.\underline{\mathrm{CH}}_{2} \mathrm{Ph}\right) 4.48\left(1 \mathrm{H}, \mathrm{m}, \underline{\left.\mathrm{CHCH}_{2}\right)} 7.28\right.$ (5H, m, aryl); m/z (GC/MS) $232(\mathrm{M})^{+}, 207,141$, 118, 98, 91, 65, 51 and 43.

Method 2 (R/S)-N-Phenylacetylaspartic acid (36.65g, $0.146 \mathrm{~mol}$ ) was partially dissolved in conc. ammonia solution $\left(220 \mathrm{~cm}^{3}\right)$. The reaction mixture was heated to reflux and the vapour allowed to escape from the reaction vessel. All solids eventually went into solution. When all the water had been evaporated, the molten residue was allowed to reach $180^{\circ} \mathrm{C}$ and was maintained at this temperature for a further $2.5 \mathrm{~h}$. The mixture was cooled and dissolved in ehtyl acetate $\left(250 \mathrm{~cm}^{3}\right)$ before the residue hardened. The organic layer was washed with saturated sodium hydrogen carbonate solution $\left(150 \mathrm{~cm}^{3}\right)$, brine $\left(150 \mathrm{~cm}^{3}\right)$ and dried with $\mathrm{Na}_{2} \mathrm{SO}_{4}$. Filtration and evaporation gave an impure brown solid product. Recrystallisation from ethyl acetate yielded the product $(2.70 \mathrm{~g}, 8 \%)$ as a white powder. M.p. $195-196^{\circ} \mathrm{C}$. All other analyses were identical to those in Method 1.

Method 3 (R/S)-N-Phenylacetylaspartic acid (50.5g, $0.20 \mathrm{~mol}$ ) was heated with finely ground ammonium carbonate $(38.28 \mathrm{~g}, 0.40 \mathrm{~mol}$ ) as of Method 1 . The product, after cooling the reaction mixture, was recrystallised from ethyl acetate yielding the product $21(3.00 \mathrm{~g}, 6 \%)$ as a white solid. M.p. $196-198^{\circ} \mathrm{C}$. All other analyses were identical to those in Method 1.

Method 4 (R/S)-N-Phenylacetylaspartic acid (100.0g, $0.40 \mathrm{~mol}$ ) was added to finely ground urea (47.9g, $0.80 \mathrm{~mol}$ ) and the mixture heated with stirring to $170^{\circ} \mathrm{C}$ for $2 \mathrm{~h}$. During this time, all solids dissolved and water vapur was observed condensing on the apparatus. The mixture was cooled and dissolved in a 50/50 water/ethyl acetate mix $\left(500 \mathrm{~cm}^{3}\right)$, separated, and the aqueous layer extracted with ethyl acetate $\left(3 \times 250 \mathrm{~cm}^{3}\right)$. The combined organics were dried $\left(\mathrm{MgSO}_{4}\right)$, filtered and evaporated to give a light brown solid. Trituration using ether yielded the product (46.80g, 51\%) as a white solid. M.p. $197-198^{\circ} \mathrm{C}$. All other analyses were identical to those in Method 1.

(S)- $\mathrm{N}$-Phenylacetylaspartic acid (30). The synthesis of $\mathbf{3 0}$ followed the same procedure as described for the racemate using phenylacetyl chloride $(107.70 \mathrm{~g}, 0.70 \mathrm{~mol}), 4 \mathrm{M}$ sodium hydroxide solution $\left(171.5 \mathrm{~cm}^{3}\right)$, (S)-aspartic acid $(92.71 \mathrm{~g}, 0.70 \mathrm{~mol})$ and $2 \mathrm{M}$ sodium hydroxide solution $\left(695 \mathrm{~cm}^{3}\right)$. The reaction yielded $30(104.41 \mathrm{~g}, 59 \%)$ as a white crystalline solid. M.p. 116- $117^{\circ} \mathrm{C}$ (Found: C, 57.5; H, 5.3: N, 5.7. $\mathrm{C}_{12} \mathrm{H}_{13} \mathrm{NO}_{5}$ requires C, 57.4; H, 5.2; N, 5.6\%); $v_{\max }$ (Nujol mull)/cm $\mathrm{cm}^{-1}$ 3412, 3332, 2965, 1738, 1706, 1647, 1545, 1467, 1345, 1289, 1244, 1193, 
1155, 989, 732; $\delta_{\mathrm{H}}\left(\mathrm{D}_{6} \mathrm{DMSO}\right) 2.65\left(2 \mathrm{H}, \mathrm{m}, \mathrm{CHCH} \underline{\mathrm{C}}_{2}\right) 3.48\left(2 \mathrm{H}, \mathrm{s}, \underline{\mathrm{CH}}_{2} \mathrm{Ph}\right) 4.55\left(1 \mathrm{H}, J_{\mathrm{ABX}} 7.0\right.$ and 6.3, $\left.\underline{\mathrm{CHCH}}_{2}\right) 7.24\left(5 \mathrm{H}, \mathrm{m}, \mathrm{CH}_{2} \underline{\mathrm{Ph}}\right) 8.46(1 \mathrm{H}, \mathrm{d}, J \mathrm{~J} .0, \mathrm{NH}) 12.60\left(2 \mathrm{H}, \mathrm{bs}, 2 \mathrm{x} \mathrm{CO}_{2} \mathrm{H}\right)$.

(S)- $\mathbf{N}$-Phenylacetylaspartimide (31). The synthesis of $\mathbf{3 1}$ followed the same procedure as for the racemate using method 4 and (S)-N-phenylacetylaspartic acid 30 (100.0g, $0.40 \mathrm{~mol}$ ) and urea (47.9g, $0.80 \mathrm{~mol})$. The impure product was triturated with hot methanol and filtered to give 31 (47.94g, 52\%) as a white solid. M.p. $196-197^{\circ} \mathrm{C}$ (Found: C, 61.8; H, 5.1; N, 12.2. $\mathrm{C}_{12} \mathrm{H}_{12} \mathrm{~N}_{2} \mathrm{O}_{3}$ requires C, 62.1; H, 5.2; N, 12.1\%); $v_{\max }\left(\right.$ Nujol mull)/cm ${ }^{-1} 3300,3178,3069,2925,2857,1731$, $1724,1645,1549,1496,1460,1357,1332,1248,1129,1177,1112,776,742,637 ; \delta_{\mathrm{H}}\left(\mathrm{D}_{6}\right.$ DMSO) 2.40-2.50 (1H, dd, $J_{\mathrm{ABX}} 17.8$ and 5.7, $\left.\mathrm{CHCH}_{2}\right)$ 2.80-2.93 (1H, dd, $J_{\mathrm{ABX}} 17.8$ and 9.4, $\left.\mathrm{CHCH}_{2}\right) 3.45\left(2 \mathrm{H}, \mathrm{s}, \underline{\mathrm{CH}_{2}} \underline{\mathrm{Ph}}\right) 4.41\left(1 \mathrm{H}, \mathrm{m}, \underline{\mathrm{CHCH}_{2}}\right) 7.26\left(5 \mathrm{H}, \mathrm{m}, \mathrm{CH}_{2} \underline{\mathrm{Ph}}\right) 8.68(1 \mathrm{H}, \mathrm{d}, J$ 7.6, NH of amide) $11.23\left(1 \mathrm{H}\right.$, bs, NH of imide); $\delta_{\mathrm{C}}\left(\mathrm{D}_{6} \mathrm{DMSO}\right) 36.04\left(\mathrm{CHCH}_{2}\right) 41.59\left(\underline{\mathrm{CH}}_{2} \mathrm{Ph}\right) 49.59$ $\left(\underline{\left.\mathrm{CHCH}_{2}\right)} 126.36\right.$ (para aryl) 128.15 (2 x meta aryl) 128.29 (2 x ortho aryl) 135.59 (quaternary

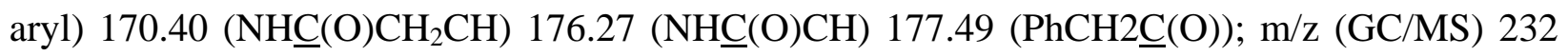
$(\mathrm{M})^{+}, 208,141,117,98,91,65,51$ and 43.

(S)- $N$-Phenylacetylaspartimido- $\alpha$-hydroxyacetic acid (32). (S)-N-Phenylacetylaspartimide 31 (25.00g, $108 \mathrm{~mol})$ was dissolved in THF $\left(250 \mathrm{~cm}^{3}\right)$ at room temperature with stirring. To this was added glyoxylic acid (50 wt\%) (31.91g, $0.216 \mathrm{~mol}$ ) and the reaction ixture was heated to reflux for $3.5 \mathrm{~h}$. Evaporation to dryness under reduced pressure produced a yellow oil which was crystallised from ethyl acetate by the dropwise addition of ether. This was recrystallised from methylated spirits yielding $32(10.10 \mathrm{~g}, 31 \%)$ as a white powder. M.p. $169-171^{\circ} \mathrm{C}$ (Found: C, 54.6; H, 4.5; N, 9.3. $\mathrm{C}_{14} \mathrm{H}_{14} \mathrm{~N}_{2} \mathrm{O}_{6}$ requires C, 54.9; H, 4.6; N, 9.15\%); $v_{\max }$ (Nujol mull)/cm ${ }^{-1}$ 3380, 2922, 2853, 2721, 2603, 2531, 1786, 1745, 1720, 1714, 1614, 1600, 1541, 14657, 1392, 1348, 1236, 1204, 1109, 972, 735; $\delta_{\mathrm{H}}\left(\mathrm{D}_{6} \mathrm{DMSO}\right) 2.40-2.50\left(1 \mathrm{H}, \mathrm{dd}, J_{\mathrm{ABX}} 17.4\right.$ and 5.4, $\left.\mathrm{CHCH}_{2}\right)$ $3.03\left(1 \mathrm{H}, \mathrm{dd}, J_{\mathrm{ABX}} 17.4\right.$ and 9.4, $\left.\mathrm{CHCH}_{2}\right) 3.49\left(2 \mathrm{H}, \mathrm{s}, \underline{\mathrm{CH}_{2}} \mathrm{Ph}\right) 4.65\left(1 \mathrm{H}, \mathrm{m}, \underline{\mathrm{CHCH}_{2}}\right) 5.52(1 \mathrm{H}, \mathrm{s}$, CHOH) $7.28\left(5 \mathrm{H}, \mathrm{m}, \mathrm{CH}_{2} \mathrm{Ph}\right) 8.78(1 \mathrm{H}, \mathrm{d}, J \mathrm{7.8}, \mathrm{NH}) ; \mathrm{m} / \mathrm{z}(\mathrm{FAB}+) 307(\mathrm{M}+\mathrm{H})^{+}, 289,261$ and 233.

(S)- $N$-Phenylacetylaspartimido- $\alpha$-chloroacetic acid (33). (S)-N-Phenylacetylaspartimido- $\alpha$ hydroxy-acetic acid 32 (2.5g, $8.2 \mathrm{mmol})$ was dissolved in dry THF $\left(50 \mathrm{~cm}^{3}\right)$ with stirring at room termperature under argon. The solution was cooled to $0^{\circ} \mathrm{C}$ before thionyl chloride $(2.37 \mathrm{~g}$, $20.0 \mathrm{mmol}$ ) was added slowly over 20 mins. Evolution of an acidic gas was observed and the mixture was allowed to warm to room temperature overnight. Ice (10g) was added and the mixture stirred for a further $3 \mathrm{~h}$. The solution was extracted using ethyl acetate $\left(3 \mathrm{x} 50 \mathrm{~cm}^{3}\right)$, the organics dried $\left(\mathrm{Na}_{2} \mathrm{SO}_{4}\right)$ filtered and evaporated to give a brown semi solid. Purification of this was achieved by recrystallising from ethyl acetate/hexane to give $33(0.80 \mathrm{~g}, 30 \%)$ as a white solid. M.p. $189-191^{\circ} \mathrm{C}$ (Found: C, 51.7; H, 4.0; N, 8.75. $\mathrm{C}_{14} \mathrm{H}_{13} \mathrm{ClN}_{12} \mathrm{O}_{5}$ requires C, 51.8; H, 4.0; $\mathrm{N}, 8.6 \%$ ); $v_{\max }\left(\right.$ Nujol mull)/cm ${ }^{-1}$ 2913, 2867, 2700, 1783, 1750, 1724, 1715, 1620, 1599, 1535, 1456, 1423, 1380, 1237, 1105, 973, 734; $\delta_{\mathrm{H}}\left(\mathrm{D}_{6} \mathrm{DMSO}\right) 2.42-2.52\left(1 \mathrm{H}\right.$, dd, $J_{\mathrm{ABX}} 17.5$ and 5.8, $\left.\mathrm{CHCH}_{2}\right)$ 2.95-3.10 (1H, $J_{\mathrm{ABX}} 17.5$ and 9.4, $\left.\underline{\mathrm{CHCH}}_{2}\right) 3.49\left(2 \mathrm{H}, \mathrm{s}, \underline{\mathrm{CH}_{2}} \underline{\mathrm{Ph}}\right) 4.63\left(1 \mathrm{H}, \mathrm{m}, \mathrm{CH}_{2} \underline{\mathrm{CH}}\right)$ $6.25(1 \mathrm{H}, \mathrm{s}, \underline{\mathrm{CHCl}}) 7.28(5 \mathrm{H}, \mathrm{m}, \mathrm{Ph}) 8.82\left(1 \mathrm{H}, \mathrm{d}, J\right.$ 7.8, NH); m/z (FAB+) $325(\mathrm{M}+\mathrm{H})^{+}, 289$, 280, 197 and 179. 
Isatin- $N$ - $\alpha$-hydroxyacetic acid methyl ester (18). Isatin (14.7g, $0.10 \mathrm{~mol})$ was dissolved in THF $\left(200 \mathrm{~cm}^{3}\right)$. Methyl glyoxylate $(17.6 \mathrm{~g}, 0.20 \mathrm{~mol})$ was added and the solution refluxed for $1.5 \mathrm{~h}$. under nitrogen. The solution was cooled, the volume reduced and the resultant oil triturated under ether to give $\mathbf{1 8}(20.4 \mathrm{~g}, 87 \%)$ as bright orange crystals. M.p. $135-138^{\circ} \mathrm{C}$ (Found: C, 56.5; H, 3.9; N, 6.1. $\mathrm{C}_{11} \mathrm{H}_{9} \mathrm{NO}_{5}$ requires $\mathrm{C}, 56.2 ; \mathrm{H}, 3.9 ; \mathrm{N}, 6.0 \%$ ); $v_{\max }$ (Nujol mull)/ $\mathrm{cm}^{-1}$ 3450, 1760, 1730, 1620; $\delta_{\mathrm{H}}\left(\mathrm{D}_{6} \mathrm{DMSO}\right) 3.70\left(3 \mathrm{H}, \mathrm{s}, \mathrm{CH}_{3}\right) 6.15(1 \mathrm{H}, \mathrm{d}, J$ 6.3, $\underline{\mathrm{CHOH}})$ 7.0-7.75 (4H, m, aromatics); m/z $235(\mathrm{M})^{+} .176$ and 147.

Method D: Isatin- $N$ - $\alpha$-acetoxyacetic acid methyl ester (22). Isatin- $N$ - $\alpha$-hydroxyacetic acid methyl ester $18(2.0 \mathrm{~g}, 8.5 \mathrm{mmol})$ was dissolved in pyridine $\left(10 \mathrm{~cm}^{3}\right)$ with stirring and cooled to $0^{\circ} \mathrm{C}$. Acetyl chloride $(0.73 \mathrm{~g}, 9.35 \mathrm{mmol})$ was added dropwise and stirred for 30 mins before being allowed to warm to room temperature for $3 \mathrm{~h}$. The solution was then poured into ice water $\left(50 \mathrm{~cm}^{3}\right)$ which resulted in the precipitation of the product. This was filtered, washed with water and dried to give 22 (1.53g, 65\%) as a dark yellow solid. M.p. 140-141 ${ }^{\circ} \mathrm{C}$. (Found: C, 56.1; H, 4.1; N, 4.9. $\mathrm{C}_{13} \mathrm{H}_{11} \mathrm{NO}_{6}$ requires $\mathrm{C}, 56.3 ; \mathrm{H}, 4.0 ; \mathrm{N}, 5.05 \%$ ); $v_{\max }$ (Nujol mull//cm ${ }^{-1} 1770,1740$, 1620, 1205; $\left.\delta_{\mathrm{H}}\left(\mathrm{CDCl}_{3}\right) 2.15\left(3 \mathrm{H}, \mathrm{s}, \mathrm{OC}(\mathrm{O}) \underline{\mathrm{CH}}_{3}\right) 3.85, \mathrm{~s}, \mathrm{CO}_{2} \underline{\mathrm{CH}}_{3}\right) 7.10(1 \mathrm{H}, \mathrm{d}, J$ 8.1, aryl) 7.12 $(1 \mathrm{H}, \mathrm{s}, \mathrm{NCH}) 7.25(1 \mathrm{H}, \mathrm{t}, J$ 6.9, aryl) $7.64(1 \mathrm{H}, \mathrm{d}, J 7.65$, aryl) $7.72(1 \mathrm{H}, \mathrm{t}, J$ 8.1, aryl); m/z 278 $(\mathrm{M}+\mathrm{H})^{+}, 2.77,218,176$ and 146.

Isatin- $N$ - $\alpha$-2,6-dichlorobenzoxyacetic acid methyl ester (23). Method D was used in the synthesis of 23 using isatin- $\mathrm{N}-\alpha$-hydroxy-acetic acid methyl ester $\mathbf{1 8}$ (2.0g, $8.5 \mathrm{mmol})$, pyridine $\left(10 \mathrm{~cm}^{3}\right)$ and 2,6-dichlorobenzoyl chloride (1.96g, $\left.9.35 \mathrm{mmol}\right)$ yielding $23(2.25 \mathrm{~g}, 62 \%)$ as a yellow powder. M.p. $105-109^{\circ} \mathrm{C}$ (Found: $\mathrm{C}$, 53.3; $\mathrm{H}$, 2.8; N, 3.6. $\mathrm{C}_{18} \mathrm{H}_{11} \mathrm{Cl}_{2} \mathrm{NO}_{6}$ requires C, 53.0; H, 2.7; N, 3.4\%); $v_{\max }$ (Nujol mull)/ $\mathrm{cm}^{-1} 1795,1760,1740,1620 ; \delta_{\mathrm{H}}\left(\mathrm{D}_{6} \mathrm{DMSO}\right) 3.90$ (3H, s, $\left.\mathrm{CH}_{3}\right)$ 7.0-7.90 (8H, m, aromatics and $\left.\mathrm{NCH}\right) ; \mathrm{m} / \mathrm{z} 408(\mathrm{M}+\mathrm{H})^{+}, 218,190$ and 146.

Isatin- $N$ - $\alpha$-phenylacetoxyacetic acid methyl ester (24). Method D was adopted using isatin- $N$ $\alpha$-hydroxy-acetic acid methyl ester $18(2.0 \mathrm{~g}, 8.5 \mathrm{mmol})$, pyridine $\left(10 \mathrm{~cm}^{3}\right)$ and phenylacetyl chloride (1.45g, $9.35 \mathrm{mmol})$ yielding $24(0.22 \mathrm{~g}, 7 \%)$ as a pale yellow powder. M.p. $100-104^{\circ} \mathrm{C}$; $v_{\max }\left(\mathrm{Nujol}\right.$ mull) $/ \mathrm{cm}^{-1} 1775,1740,1675,1620 ; \delta_{\mathrm{H}}\left(\mathrm{D}_{6}\right.$ acetone) $3.75\left(3 \mathrm{H}, \mathrm{s}, \mathrm{CH}_{3}\right) 3.90(2 \mathrm{H}, \mathrm{s}$, $\left.\mathrm{CH}_{2}\right)$ 7.10-7.70 (10H, m, aromatics and $\left.\mathrm{NCH}\right) ; \mathrm{m} / \mathrm{z} 354(\mathrm{M}+\mathrm{H})^{+}, 353,294,218$ and 146.

Isatin- $N$ - $\alpha$-chloroacetic acid methyl ester (25). Isatin- $\mathrm{N}$ - $\alpha$-hydroxy-acetic acid methyl ester 18 (0.50g, $2.13 \mathrm{mmol})$ was dissolved in THF $\left(50 \mathrm{~cm}^{3}\right)$ and cooled with stirring to $-15^{\circ} \mathrm{C}$. To this was added thionyl chloride $(0.30 \mathrm{~g}, 2.52 \mathrm{mmol})$ and triethylamine $(0.26 \mathrm{~g}, 2.52 \mathrm{mmol})$ dropwise over 10 mins. The solution was stirred for a further $3 \mathrm{~h}$. until a white precipitate formed. The solution was diluted with $\mathrm{CH}_{2} \mathrm{Cl}_{2}\left(200 \mathrm{~cm}^{3}\right)$ and washed with $0.1 \mathrm{M} \mathrm{HCl}\left(2 \times 50 \mathrm{~cm}^{3}\right)$ and saturated brine $\left(50 \mathrm{~cm}^{3}\right)$. The organics were dried using $\mathrm{MgSO}_{4}$, filtered and evaporated to dryness to leave an orange sticky solid. Trituration using chloroform gave $22(0.16 \mathrm{~g}, 30 \%)$ as bright orange crystals. M.p. $114-117^{\circ} \mathrm{C} ; v_{\max }$ (Nujol mull) $/ \mathrm{cm}^{-1} 1760,1740,1620 ; \delta_{\mathrm{H}}\left(\mathrm{D}_{6}\right.$ DMSO $3.80\left(3 \mathrm{H}, \mathrm{s}, \mathrm{CH}_{3}\right)$ 6.80-7.80 (7H, m, aromatics and $\left.\mathrm{NCH}\right) ; \mathrm{m} / \mathrm{z} 255(\mathrm{M})^{+}\left(\mathrm{Cl}^{37}\right), 253$ $(\mathrm{M})^{+}\left(\mathrm{Cl}^{35}\right), 218$ and 146.

Isatin- $N$ - $\alpha$-bromoacetic acid methyl ester (26). Isatin- $\mathrm{N}-\alpha$-hydroxy-acetic acid methyl ester 18 $(0.50 \mathrm{~g}, 2.13 \mathrm{mmol})$ was dissolved in glacial acetic acid $\left(10 \mathrm{~cm}^{3}\right)$ with stirring at room 
temperature. Bromine $(0.34 \mathrm{~g}, 2.13 \mathrm{mmol})$ then hydrogen bromide $(0.17 \mathrm{~g}, 2.13 \mathrm{mmol})$ were added dropwise to the solution and this was left to stir overnight. (Water $\left(50 \mathrm{~cm}^{3}\right)$ was added to the deep red solution and this extracted with chloroform $\left(3 \times 50 \mathrm{~cm}^{3}\right)$. The organic layer was washed with dilute sodium metabisulphite solution $\left(2 \times 50 \mathrm{~cm}^{3}\right)$, dried over $\mathrm{MgSO}_{4}$, filtered and evaporated to dryness to give $26(0.26 \mathrm{~g}, 415)$ as an orange powder. M.p. $130-132^{\circ} \mathrm{C}$; $v_{\max }$ (Nujol mull $) / \mathrm{cm}^{-1} 1740,1620 ; \delta_{\mathrm{H}}\left(\mathrm{D}_{6} \mathrm{DMSO}\right) 3.70\left(3 \mathrm{H}, \mathrm{s}, \mathrm{CH}_{3}\right)$ 7.10-7.90 $(4 \mathrm{H}, \mathrm{m}$, aromatics and $\mathrm{NCH}) ; \mathrm{m} / \mathrm{z} 299(\mathrm{M})^{+}\left(\mathrm{Br}^{81}\right), 297(\mathrm{M})^{+}\left(\mathrm{Br}^{79}\right), 240,238,227$ and 225.

Isatin-3-O-benzyl oxime Isatin $(14.7 \mathrm{~g}, 0.1 \mathrm{~mol})$ was dissolved in water $\left(500 \mathrm{~cm}^{3}\right)$ and Obenzylhydroxylamine hydrochloride $(17.56 \mathrm{~g}, 0.11 \mathrm{~mol})$ was added and the solution refluxed for $1 \mathrm{~h}$. A precipitate appeared in cooling which was filtered and recrystallised from toluene to give the product (14.83g, 59\%) as bright yellow crystals on filtration. M.p. $160-161^{\circ} \mathrm{C}$; $v_{\max }$ (Nujol mull) $/ \mathrm{cm}^{-1} 1736,1694,1609 ; \delta_{\mathrm{H}}\left(\mathrm{D}_{6} \mathrm{DMSO}\right) 5.50\left(2 \mathrm{H}, \mathrm{s}, \mathrm{CH}_{2}\right) 6.85(1 \mathrm{H}, \mathrm{d}, J$ 7.7, aryl) 7.00 $(1 \mathrm{H}, \mathrm{t}, J$ 7.7, aryl) 7.35-7.50 (6H, m, aromatics) $7.75(1 \mathrm{H}, \mathrm{d}, J$ 7.5, aryl) $10.85(1 \mathrm{H}, \mathrm{s}, \mathrm{NH}) ; \mathrm{m} / \mathrm{z}$ $253(\mathrm{M}+\mathrm{H})^{+}, 252$ and 145.

Isatin- $N$ - $\alpha$-hydroxyacetic acid-4-nitrobenzyl-ester-3-O-benzyl oxime (27). p-Nitrobenzyl glyoxylate $(10.0 \mathrm{~g}, 44.1 \mathrm{mmol})$ was dissolved in toluene $\left(150 \mathrm{~cm}^{3}\right)$ and the solution refluxed for 1h. with a Dean and Stark apparatus attached. After cooling, isatin-3-benzyloxime (5.56g, $22.0 \mathrm{mmol}$ ) was added and the solution refluxed overnight. After cooling, the volume was reduced and the resultant oil triturated to give $27(4.62 \mathrm{~g}, 46 \%)$ as a yellow powder. M.p. 135$137^{\circ} \mathrm{C}$ (Found: C, 62.4; H, 4.2; N, 9.0. $\mathrm{C}_{24} \mathrm{H}_{19} \mathrm{~N}_{3} \mathrm{O}_{7}$ requires C, 62.6; H, 4.1; N, 9.1\%)' $v_{\max }$ (Nujol mull)/ $/ \mathrm{cm}^{-1} 3286,1759,1714,1606,1515,1347 ; \delta_{\mathrm{H}}\left(\mathrm{D}_{6} \mathrm{DMSO}\right) 5.35\left(2 \mathrm{H}, \mathrm{s}, \mathrm{NO}_{2} \mathrm{PhCH}_{2}\right.$ ) $5.50\left(2 \mathrm{H}, \mathrm{s}, \mathrm{PhCH}_{2}\right) 6.30(1 \mathrm{H}, \mathrm{d}, J 5.3, \mathrm{NCH}) 7.10(1 \mathrm{H}, \mathrm{d}, J$ 8.0, aryl) $7.20(1 \mathrm{H}, \mathrm{t}, J$ 7.4, aryl) 7.30-7.60 (8H, m, aromatics) 7.95 (1H, d, $J$ 7.0, aryl) 8.15 (2H, d, $J$ 8.75, para aryl).

Isatin- $N$ - $\alpha$-acetoxyacetic acid-4-nitrobenzyl-ester-3-O-benzyl oxime (28). Method D was used in the formation of $\mathbf{2 8}$ using isatin-N- $\alpha$-hydroxy-acetic acid-4-nitrobenzyl-ester-3-O-benzyl oxime $27(1.00 \mathrm{~g}, 2.17 \mathrm{mmol})$, acetyl chloride $(0.19 \mathrm{~g}, 2.39 \mathrm{mmol})$ and pyridine $\left(10 \mathrm{~cm}^{3}\right)$ to give 28 (0.52g, 48\%) as a pale yellow solid. M.p. $152-155^{\circ} \mathrm{C}$ (Found: C, 62.1; H, 4.3; N, 8.3. $\mathrm{C}_{26} \mathrm{H}_{21} \mathrm{~N}_{3} \mathrm{O}_{8}$ requires C, 62.0; H, 4.2; N, 8.35\%); $v_{\max }$ (Nujol mull)/cm ${ }^{-1} 1758,1744,1606,1513$; $\delta_{\mathrm{H}}\left(\mathrm{D}_{6} \mathrm{DMSO}\right) 2.20\left(3 \mathrm{H}, \mathrm{s}, \mathrm{CH}_{3}\right) 5.40\left(2 \mathrm{H}, \mathrm{s}, \mathrm{CO}_{2} \underline{\mathrm{CH}}_{2}\right) 5.55\left(2 \mathrm{H}, \mathrm{s}, \mathrm{CH}_{2} \mathrm{ON}\right) 7.05(1 \mathrm{H}, \mathrm{d}, J$ J 7.9 , aryl) $7.20\left(1 \mathrm{H}, \mathrm{t}, J 7.25\right.$, aryl) $7.25\left(1 \mathrm{H}, \mathrm{s}, \mathrm{NCH}_{-} 7.35-7.55(8 \mathrm{H}, \mathrm{m}\right.$, aromatics) 7.95 (1H, d, $J$ 7.7, aryl) $8.15\left(2 \mathrm{H}, \mathrm{d}, J\right.$ 8.7, para aryl); $\mathrm{m} / \mathrm{z} 504(\mathrm{M}+\mathrm{H})^{+}$.

Isatin- $N$ - $\alpha$-2,6-dichlorobenzoxyacetic acid-4-nitrobenzyl-ester-3-O-benzyl oxime (29). Method D was used in the formation of $\mathbf{2 9}$ using isatin-N- $\alpha$-hydroxy-acetic acid-4-nitrobenzylester-3-O-benzyl oxime 27 (1.00g, $2.17 \mathrm{mmol})$, 2,6-dichlorobenzoyl chloride (0.50g, $2.39 \mathrm{mmol})$ and pyridine $\left(10 \mathrm{~cm}^{3}\right)$ to give $29(0.35 \mathrm{~g}, 25 \%)$ as a yellow solid. M.p. $110-112^{\circ} \mathrm{C}$ (Found: C, 58.4; H, 3.6; N, 6.5. $\mathrm{C}_{31} \mathrm{H}_{21} \mathrm{Cl}_{2} \mathrm{~N}_{3} \mathrm{O}_{8}$ requires C, 58.7; H, 3.3; N, 6.6\%); $v_{\max }$ (Nujol mull)/cm ${ }^{-1}$ 1736, 1606, 1516; $\delta_{\mathrm{H}}\left(\mathrm{D}_{6} \mathrm{DMSO}\right) 5.40\left(2 \mathrm{H}, \mathrm{s}, \mathrm{CO}_{2} \underline{\mathrm{CH}}_{2} \mathrm{ON}\right) 6.99(1 \mathrm{H}, \mathrm{d}, J$ 7.8, aryl) $7.05(1 \mathrm{H}, \mathrm{t}$, $J$ 7.5, aryl) 7.25 (1H, t, $J$ 6.9, aryl) 7.35-7.80 (11H, m, aromatics) 7.95 (1H, d, $J$ 7.8, aryl) 8.15 (2H, d, $J$ 8.0, para aryl). 
Kinetic Studies. The second-order rate constants for alkaline hydrolysis of the $\gamma$-lactams were obtained as previously described. ${ }^{12}$ The inhibition studies were also undertaken as described elsewhere. $^{24}$

\section{Acknowledgements}

We are grateful to EPSRC/BBSRC for support (Biomolecular Sciences) and AstraZeneca for the supply of some chemicals and antibacterial testing.

\section{References}

1. (a) Strominger, J. L. Antibiotics 1967, 1, 706. (b) Woodward, R. B. The Chemistry of Penicillin, Clarke, H. T.; Johnson, J. R.; Robinson, R., Eds; Princeton University Press: Princeton, New Jersey, 1949; p 443.

2. Page, M. I. Adv. Phys. Org. Chem. 1987, 23, 165.

3. Page, M. I. The Chemistry of ß-Lactams, Page, M. I. Ed.; Blackie: Glasgow, 1992; p 79.

4. (a) Mardle, M. J.; Nayler, J. H. C.; Rustidge D. W.; Waddington, H. R. J. J. Chem. Soc. (C) 1968, 237. (b) Miller, D. B.; Nayler, J. H. C.; Waddington, H. R. J. J. Chem. Soc. (C) 1968, 242.

5. Varma, R. S.; Nobles, W. L. J. Pharm. Sci. 1975, 64, 881.

6. Jungheim, L. N.; Boyd, D. B.; Indelicato, J. M.; Pasini, C. E.; Preston, D. A.; Alborn Jr. W. E. J. Med. Chem. 1991, 34, 1732.

7. Marchand-Brynaert, J.; Bounkhala-Khrouz, Z.; Carretero, J. C.; Davies, J.; Ferroud, D.; Keulen, van J .; Serckx-Poncin, B.; Ghosez, L. Recent Advances in the Chemistry of $\beta$ Lactam Antibiotics, Bentley, P. H.; Southgate, R.; Eds., Roy. Soc. Chem.: London, 1989; p 157.

8. Baldwin, J. E.; Lowe, C.; Schofield, C. J. Tetrahedron Lett. 1990, 31, 2211.

9. Marchand-Brynaert, J.; Amadei, E.; Ghosez, L. Bull. Soc. Chim. Belg. 1994, 103, 213.

10. Frère, J-M.; Nguyen-Disteche, M.; Coyette, J.; Joris, B. The Chemistry of ß-Lactams, Page, M. I. Ed.; Blackie: Glasgow, 1992; p148.

11. Barker, C. V.; Korn, S. R.; Monteith, M.; Page, M. I. Chem. Commun. 1999, 721.

12. Casey, L. A.; Galt, R. B.; Page, M. I. J. Chem. Soc., Perkin Trans. 2 1993, 23.

13. (a) Boyd, D. B. Chemistry and Biology of B-Lactam Antibiotics, Morin, R. B.; Gorman, M. Eds, Academic Press: New York, 1982; Vol. 1, pp 437-545. (b) Cohen, N. C. J. Med. Chem. 1983, 26, 259.

14. Serino, A. J. J. Org. Chem. 1988, 53, 2661.

15. Herzberg, O.; Moult, J. Science 1987, 236, 694. 
16. Samroioui, B.; Sutten, B. J.; Todd, R. J.; Artymiuk, P. J.; Waley, S. G.; Phillips, S. G. Nature (London) 1986, 320, 378.

17. Kelly, J. A.; Dideberg, O.; Charlier, P.; Wery, J-P.; Libert, M.; Moews, P. C.; Knox, J. P.; Duez, C.; Fraipoint, C. I.; Joris, B.; Dusart, J.; Frère, J-M.; Ghuysen, J-M. Science 1986, 231, 1429.

18. Dideberg, O.; Charlier, P.; Wery, J-P.; Dehottay, P.; Dusart, J.; Erpicum, T.; Frère, J-M.; Ghuysen, J-M. Biochem. J. 1987, 245, 911.

19. Moews, P. C.; Knox, J. P.; Dideberg, O.; Charlier, P.; Frère, J-M. Proteins 1990, 7, 156.

20. Subramanyam, C.; Bell, M. R.; Carabateas, P.; Court, J. J.; Dority, J. A.; Ferguson, E.; Gordon, R.; Hlasta, D. J.; Kumar, V.; Saindane, M. J. Med. Chem. 1994, 37, 2623.

21. March, J. Advanced Organic Chemistry, $4^{\text {th }}$ Edn; John Wiley and Sons: New York; p 435.

22. Sykes, N.; McDonald, S. J. F.; Page, M. I. J. Med. Chem. 2002, 45, 2850.

23. Jones, M.; Buckwell, S. C.; Page, M. I.; Wrigglesworth, R. J. Chem. Soc., Chem. Commun. 1989, 70 . 